\title{
Using Data from Earth Observation to Support Sustainable Development Indicators: An Analysis of the Literature and Challenges for the Future
}

\author{
Ana Andries ${ }^{1, * \mathbb{D}}$, Stephen Morse ${ }^{1} \mathbb{D}$, Richard J. Murphy $^{1} \mathbb{D}$, Jim Lynch $^{1}$ and Emma R. Woolliams ${ }^{2} \mathbb{D}$ \\ 1 Centre for Environment and Sustainability, University of Surrey, Guildford GU2 7XH, UK; \\ s.morse@surrey.ac.uk (S.M.); rj.murphy@surrey.ac.uk (R.J.M.); j.lynch@surrey.ac.uk (J.L.) \\ 2 Climate and Earth Observation Group, National Physical Laboratory, Teddington TW11 0LW, UK; \\ emma.woolliams@npl.co.uk \\ * Correspondence: a.andries@surrey.ac.uk
}

check for

updates

Citation: Andries, A.; Morse, S.; Murphy, R.J.; Lynch, J.; Woolliams, E.R. Using Data from Earth Observation to Support Sustainable Development Indicators: An Analysis of the Literature and Challenges for the Future. Sustainability 2022, 14, 1191. https://doi.org/10.3390/su14031191 Academic Editor: Jamal Jokar Arsanjani

Received: 11 December 2021

Accepted: 17 January 2022

Published: 21 January 2022

Publisher's Note: MDPI stays neutral with regard to jurisdictional claims in published maps and institutional affiliations.

Copyright: (c) 2022 by the authors. Licensee MDPI, Basel, Switzerland. This article is an open access article distributed under the terms and conditions of the Creative Commons Attribution (CC BY) license (https:/ / creativecommons.org/licenses/by/ $4.0 /)$.

\begin{abstract}
The Sustainable Development Goals (SDG) framework aims to end poverty, improve health and education, reduce inequality, design sustainable cities, support economic growth, tackle climate change and leave no one behind. To monitor and report the progress on the 231 unique SDGs indicators in all signatory countries, data play a key role. Here, we reviewed the data challenges and costs associated with obtaining traditional data and satellite data (particularly for developing countries), emphasizing the benefits of using satellite data, alongside their portal and platforms in data access. We then assessed, under the maturity matrix framework (MMF 2.0), the current potential of satellite data applications on the SDG indicators that were classified into the sustainability pillars. Despite the SDG framework having more focus on socio-economic aspects of sustainability, there has been a rapidly growing literature in the last few years giving practical examples in using earth observation (EO) to monitor both environmental and socio-economic SDG indicators; there is a potential to populate 108 indicators by using EO data. EO also has a wider potential to support the SDGs beyond the existing indicators.
\end{abstract}

Keywords: earth observation; SDGs; indicator type; data challenges

\section{Introduction}

In 2012, the United Nations (UN) Conference on Sustainable Development (Rio + 20) was held in Rio de Janeiro; 193 member states agreed on a new and comprehensive framework called the Sustainable Development Goals (SDGs). The SDG framework was intended to be an integrated development agenda to 2030 that would apply equally to developed and developing countries and address all three dimensions of sustainable development (environment, social and economic) and their interlinkages [1].

The SDGs were ratified by the UN General Assembly at the Sustainable Development Summit in New York on 25 September 2015. All signatory countries committed to monitoring their progress towards the 17 goals at the heart of the SDGs by assessing past and current conditions at national and sub-national levels. To achieve this, the UN created a framework of 169 targets and 232 unique indicators that are meant to frame national agendas and policies up to 2030 [2].

The Inter-Agency Expert Group for the SDGs (IAEG-SDGs) established three working groups responsible for formulating these indicators and targets, as well as methods for 'populating' the indicators with appropriate data and communication and coordination with all partners (international organisations, civil society, governments, academia, and the private sector). The IAEG-SDGs Global Indicator Framework was officially adopted by the UN Statistical Commission in March 2017 [3] and, initially, the IAEG-SDGs classified the indicators into three different tiers based on how well established the methodology 
was at that time and the data available to allow the population of the indicators: Tier I (well-established methodology and data are widely available), Tier II (well-established methodology but data are not collected regularly by the countries), and Tier III (no established methodology to collect the required data and data are not available). Each of the SDG indicators has a set of metadata guidelines to aid interpretation and transferability; these include indicator definition (objective and purpose), computational methodology (refers to how the indicator is computed and disaggregated into multiple sub-indicators) and sourcing of data (the main source of data, collecting method, the frequency of data collection, data providers and data availability) [4].

The IAEG-SDGs regularly reviews the Global Indicator Framework to add more indicators, alter existing ones and, if required, update the status of the tier categorisation of the indicator (see Table 1).

Table 1. SDG indicator framework and tier classification update [3,5].

\begin{tabular}{cccc}
\hline $\begin{array}{c}\text { Date of SDG Indicator } \\
\text { Framework Update }\end{array}$ & $\begin{array}{c}\text { Number of } \\
\text { Indicators }\end{array}$ & Indicator Amendments & $\begin{array}{c}\text { Indicator Tier } \\
\text { Classification }\end{array}$ \\
\hline $\begin{array}{c}\text { March 2016 (original } \\
\text { framework) }\end{array}$ & 232 & N/A & $\begin{array}{c}93 \text { Tier I } \\
66 \text { Tier II } \\
68 \text { Tier III } \\
\text { multiple tiers }\end{array}$ \\
\hline December 2020 & 231 & $\begin{array}{c}36 \text { changes in which 14 } \\
\text { indicators were proposed to } \\
\text { replace existing ones, } 8 \\
\text { indicators were revised, } 8 \\
\text { proposals were made for } \\
\text { additional indicators, and 6 } \\
\text { indicators were recommended } \\
\text { for removal }\end{array}$ & $\begin{array}{c}\text { 130 Tier I } \\
\text { multiple tiers }\end{array}$ \\
\hline March 2021 & No modifications & No modifications \\
\hline
\end{tabular}

To populate the IAEG-SDG indicators at the country level, many different types of data are required; these are mostly derived from eight sources: census data (CD), household surveys (HS), agricultural survey (AS), administrative data (AD), Civil registration (CR), economic statistics (ES), geospatial data (GD), and other environmental data (Env) (Table 2) [6]. However, data alone are not enough, as they must be transformed (e.g., data combined to generate a single indicator), analysed, interpreted, and communicated to those who would make use of the indicators. Therefore, the UN noted a requirement to "intensify efforts to strengthen statistical capacities of developing countries and least developed countries are among the particular cases that need special attention in this regard" ([2], paragraph 74). This includes a requirement to ensure access to quality and disaggregated data, including geospatial and earth observation (EO)-derived data [2]. Environmental data can include in situ observations, ground-based or aircraft remote sensing or satellite remote sensing. Here we use the broad term earth observation (EO) to describe predominantly satellitebased remote sensing. This term often also includes remote sensing from both crewed and autonomous aircraft where similar imaging techniques are used.

Geospatial data play a crucial role for many of the SDG indicators, as well as for disaggregated analysis of socioeconomic SDG indicators [6-10]. For instance, converting household surveys into geospatial data can facilitate disaggregation and analysis by spatial characteristics, e.g., proximity to roads or levels of urban development [6]. In recent years, there have been efforts to integrate the geospatial approach into the national statistics offices (NSOs) of many countries [11]. Likewise, geospatial tools can easily manipulate large datasets such as those derived from EO satellites, aerial photography (AP), lidar, information and communications technologies (ICT) (e.g., social media, mobile, and crowdsourcing data). The processing to derive information products from these different sources is increasingly dependent on artificial intelligence and machine learning. These tools can manipulate large data sets and the artificial intelligence methods are often referred to collectively as 'big data' or the 'data revolution' [6-8]. Processing and analysing large datasets 
in real-time can reveal patterns, trends, and interactions, thereby deriving information and insights on human behaviours and wellbeing, and helping to target aid interventions to help vulnerable people [12].

Table 2. Data type and challenges associated.

\begin{tabular}{|c|c|c|c|}
\hline Data Source & Data Type & Description & Data Challenges \\
\hline \multirow{6}{*}{$\begin{array}{l}\text { Traditional } \\
\text { national } \\
\text { statistical data }\end{array}$} & Census data (CD) & $\begin{array}{l}\text { CD is a systematic recording of information, focusing } \\
\text { mainly on the population and takes place at least once } \\
\text { every } 10 \text { years (varies between countries); NSOs are } \\
\text { responsible for collecting these data. }\end{array}$ & \multirow{3}{*}{$\begin{array}{l}\text { Challenges in obtaining quality data } \\
\text { - } \quad \text { lack of data accessibility and } \\
\text { availability, data quality, data } \\
\text { continuity, transparency, and } \\
\text { accountability } \\
\text { - lack of funding/financing }\end{array}$} \\
\hline & $\begin{array}{l}\text { Household surveys } \\
\text { (HS) }\end{array}$ & HS provides demographic and socio-economic data. & \\
\hline & $\begin{array}{l}\text { Agricultural survey } \\
\text { (AS) }\end{array}$ & $\begin{array}{l}\text { AS covers information about land use and ownership, } \\
\text { operator characteristics, production practices, crop } \\
\text { yields and productivity, income, and expenditures. }\end{array}$ & \\
\hline & $\begin{array}{l}\text { Administrative data } \\
\text { (AD) }\end{array}$ & $\begin{array}{l}\text { ADs are collected by government departments and } \\
\text { include information about welfare, tax, health, and } \\
\text { educational record systems. }\end{array}$ & \multirow{3}{*}{$\begin{array}{l}\text { Challenges in data processing } \\
\text { - } \quad \text { difference in methodology } \\
\text { - } \quad \text { limited human and technical } \\
\text { capacity (e.g., skills and training, } \\
\text { adequate staff) } \\
\text { - lack of developed infrastructure } \\
\text { to support networking, } \\
\text { high-performance computing, } \\
\text { and the use of digitalisation }\end{array}$} \\
\hline & Civil registration $(\mathrm{CR})$ & $\begin{array}{l}\text { CR is a collection of data that records main events in a } \\
\text { person's life (such as birth, marriage, divorce, } \\
\text { adoption, and death). The primary responsibility for } \\
\text { collecting such data is typically attributed to different } \\
\text { Ministries and National Statistical Offices (NSOs). }\end{array}$ & \\
\hline & Economic statistics (ES) & $\begin{array}{l}\text { ES typically include data on the labour force, tax } \\
\text { returns, trade statistics, etc. The scope of these data are } \\
\text { to measure the financial performance of economic } \\
\text { agents and can include estimates of Gross Domestic } \\
\text { Product, Gross National Income, national poverty } \\
\text { levels, household income, labour force participation } \\
\text { and employment status, and economic losses from } \\
\text { disasters. }\end{array}$ & \\
\hline \multirow{5}{*}{$\begin{array}{l}\text { Non-traditional } \\
\text { data }\end{array}$} & & & Challenges in using EO data \\
\hline & Geospatial data (GD) & $\begin{array}{l}\text { GD refers to all data from previous categories that are } \\
\text { located with environmental data, that include } \\
\text { geolocation as coordinates and topology, allowing the } \\
\text { data to be illustrated geographically. } \\
\text { Environmental data can be derived from readily } \\
\text { available imagery from satellites, airborne, drones, etc. } \\
\text { at different spatial resolutions that are coupled with } \\
\text { geospatial tools. Satellite imagery is currently used to } \\
\text { populate environmental indicators linked to }\end{array}$ & 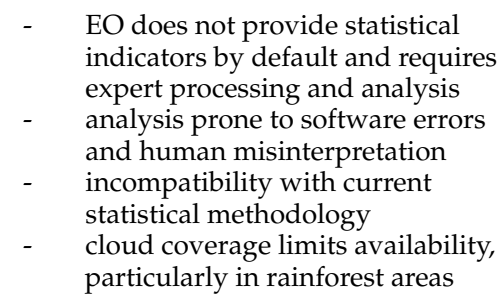 \\
\hline & & agriculture, biodiversity, forestry and land cover and & \multirow{3}{*}{ 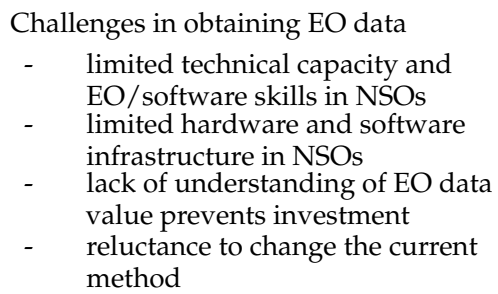 } \\
\hline & & use change. & \\
\hline & $\begin{array}{l}\text { Environmental data } \\
(\text { Env) }\end{array}$ & $\begin{array}{c}\text { Other environmental data refers to ground } \\
\text { technologies or surveys. Many environmental } \\
\text { indicators also include real-time monitoring of } \\
\text { conditions, such as air quality in urban areas or water } \\
\text { supply. }\end{array}$ & \\
\hline
\end{tabular}

However, of all these elements, the one area that is perhaps still in its infancy is the use of EO technology to populate the IAEG-SDG indicators (herein referred to as the SDG indicators) particularly for those indicators in the social and economic domains of sustainable development. Using EO technology for social and economic domains is an area of active research; much progress has been made in recent years as the availability of satellite data and tools to manipulate them are more readily available. Notwithstanding this progress, much remains to be done; the time is now right to review the current state-ofthe-art and chart a path for the future.

Therefore, the purpose of this paper is to provide a conceptual review [13] of the literature focusing on efforts to use EO technology in populating the SDG indicators. The paper structure is presented in Figure 1 and it begins with an analysis of the literature of data challenges (including cost) behind populating the SDG indicators before moving on to 
explore the potential of using EO derived data. As part of this, it is necessary to give the reader a sense of how EO technology has progressed to date and the authors have included Supplementary Materials which set out some of the technical capabilities of EO-based instruments, EO data portals and data platforms currently available. Our review highlights the main applications of satellite imagery in sustainability and later links to peer-reviewed articles and best practices of populating SDG indicators. The paper applies a framework first developed by Andries et al. [14,15] designed to assess the potential of EO for the SDG indicators and expands it by considering the classification of indicators into the various indicator types based on the sustainable development pillars. This analysis was designed to identify the areas where more work is needed in the use of EO data for indicators, but also to understand the field that has been covered in recent years.

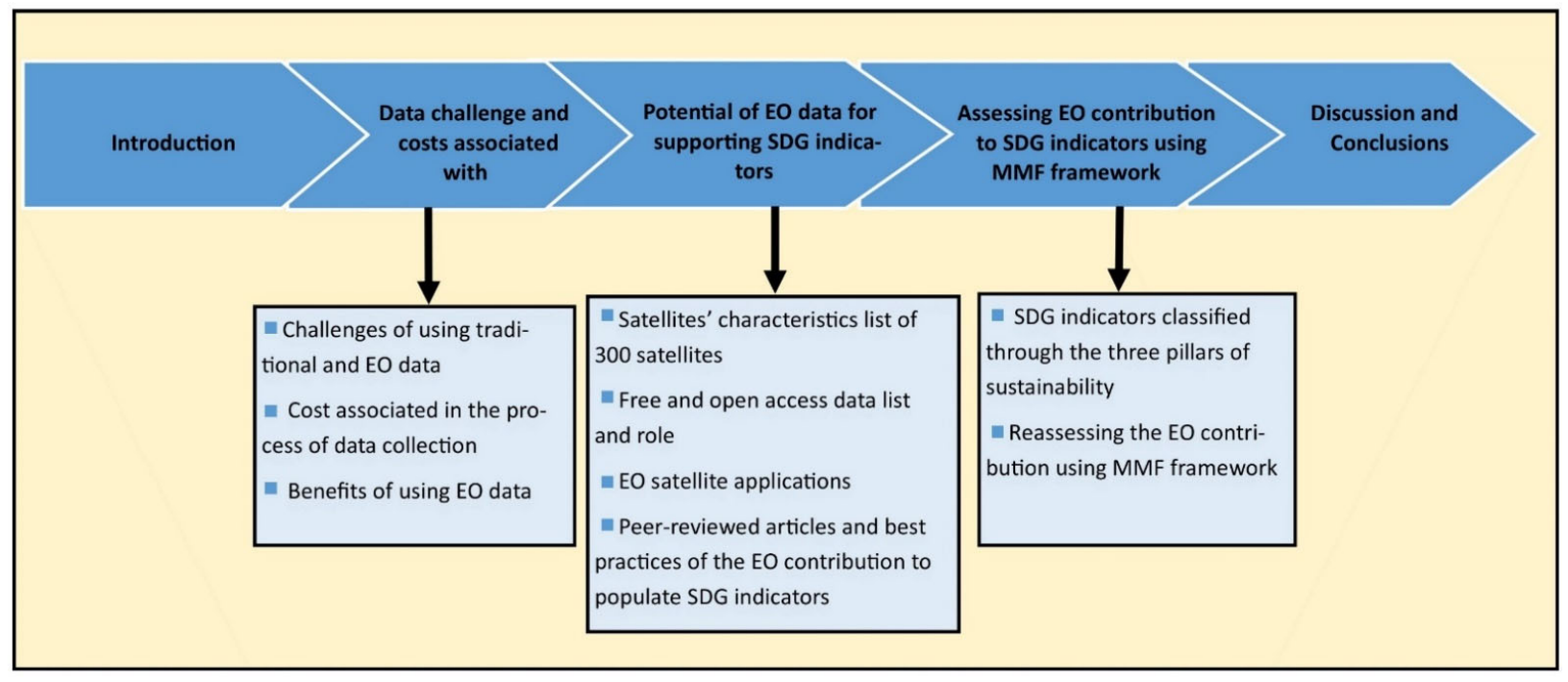

Figure 1. Paper structure.

\section{Data Challenges and Costs}

Results from the Voluntary National Reviews (VNRs) 2019 [16], a process by which each country assesses progress made in achieving the SDGs every year, showed that most developing countries failed to populate the SDG indicators due to a lack of data. However, even when data are available, countries can encounter other challenges as highlighted in Table 2 [17].

Developing countries tend to have relatively weak statistical institutions with poor governance, constraints in obtaining quality data, a lack of time series [11], and often have large variations in data collection and presentation methodologies across space and time [18]. Kindornay et al. [19] highlighted other issues, such as lack of investment in staff, infrastructure, and tools (e.g., computers and software), low human capacity, highly fragmented statistical systems, and inadequate funding, most of these issues are under political influence; thus, data may even be misreported and suppressed for political reasons [20]. All of these issues can make indicator comparisons unreliable [11,16-18,21,22] (see Table 2).

Regarding EO-derived data, a survey conducted by the Intergovernmental Group on Earth Observations (GEO) [23], with 72 respondents from GEO's member countries, revealed a series of challenges that cover organisational, technical capacity and data accessibility issues for NSOs to obtain the necessary data (Table 2). However, according to the UN Global Working Group on Big Data survey, 60\% of interviewees (within 93 countries) noted that the main benefits of using big data from satellite imagery and other sources are "faster and more timely effective statistics", "modernisation of the statistical production process", generating "new products and services", and "cost reductions" [24]. There have been challenges regarding the temporal resolution (revisit times) of EO satellites when these data are used for certain sensitive applications; however, in recent years there has 
been a shift from multi-day revisit times to daily revisit times [25], particularly through the establishment of small satellite constellations such as CubeSats, SkySat, and Vivid-I, which are able to close this temporal resolution gap [26]. In addition, cloud coverage, particularly in tropical areas, and satellite sensor failure can result in data gaps; this may limit their applicability. However, algorithms have been developed and are now often easily accessible on online computational platforms and portals (e.g., Google Earth Engine), which can partially fill in such data gaps $[27,28]$.

Given recent developments in satellite programmes, many have noted that there is a need to invest in geospatial departments in NSOs, ensuring adequate human capacity with relevant skills, equipment, and software and policy frameworks to support the collection and use of EO data; countries also need to be open to reform in their institutional and regulatory context [29]. For example, the Applied Sciences Programme within the National Aeronautics and Space Administration (NASA) Earth Science Division has been implementing free training on the practical use of satellite data, covering the application of EO to disaster management, water quality management, health care (e.g., malaria early warning), fisheries management, air quality monitoring, and wildfires [30,31].

Jerven [32] made one of the first estimations of the financial costs of populating the SDG indicators in the policy paper 'Benefits and Costs of the Data for Development Targets for the Post2015 Development Agenda', later elaborated in [33]. In both reports, Jerven estimated a global cost of US \$254 billion for populating the SDG indicators over the 2016-2030 period, taking into account the need for the population census, living standards measurement studies, demographic and health surveys, core welfare indicator questionnaires, and multiple indicator cluster surveys. However, Demombynes and Sandefur [34] provided a much lower estimated cost of US $\$ 4.5$ billion to populate the SDG indicators over the same period. However, these estimates do not consider the use of EO and 'big data', despite the UN "Data for Development" report (2015) suggestions that "cost savings might result from the use of new technologies" and should result in better quality and efficiency, and that the new technologies "may yield lower costs in the long run, but in the near term, they are likely to require new investments" ([6] p. 29). The report estimated a total cost of populating the SDG indicators to be US $\$ 902$ to US\$941 million per annum for all data types across 77 developing countries, where US $\$ 787$ million would be attributed to traditional national statistical data and US\$114 million to EO data (Table 2).

EO derived data are increasingly being recognised as a promising resource for tackling the challenges involved in data collection for indicators and the Integrated United Nations Committee of Experts on Global Geospatial Information Management (UN-GGIM) and GEO play key roles in realising this promise. These agencies are working with statistical communities, at both global and national levels, to support them on how they could benefit from the use of EO data to monitor SDGs. As a result, NSOs in countries such as South Africa, the United Kingdom, Nigeria, Philippines, Sweden [27], USA [35], Colombia, Senegal, Sierra Leone, Kenya, Tanzania and Ghana [36] have started exploring the use of EO satellite imagery and geospatial frameworks, especially to address indicators of SDGs 1 (End Poverty), 2 (Zero Hunger), 6 (Clean water and sanitation), 11 (Sustainable cities), 13 (Climate Action), and 15 (Life on Land). EO data can also provide opportunities to measure the indicator at the subnational level [35].

\section{Potential of Earth Observation (EO) for Supporting SDG Indicators}

The era of observing the Earth through satellites began in 1957 with the launch of the first satellites (Sputnik-1 and Sputnik-2) by the Soviet Union followed soon after (1958 to 1959) by NASA launching the Explorer satellite series. While images of the Earth had been captured by sub-orbital craft in the 1940s, the first orbital satellite image of the Earth was captured by Explorer 6 in 1959 [37]. Technology progressed rapidly and, in 1972, Landsat 1 provided the first images with a resolution of $80 \mathrm{~m}$, followed by the European Space Agency (ESA) that has observed the Earth from space since the launch of its first meteorological mission in 1977 and later by European Remote Sensing (ERS) and Envisat 
missions satellites [38]. Today the main space agencies provide high-resolution satellite data at no cost to the user, including Landsat from NASA with $30 \mathrm{~m}$ and ESA Sentinel 2 with up to $10 \mathrm{~m}$ resolutions.

There are currently 260 operational EO satellites (having full functionality), 333 nonoperational (usually historical satellites that have stopped sending data for several reasons) and approximately 200 satellites are in development (this includes satellites that have been approved and planned to be launched).

However, it needs to be noted here that a single satellite may carry several instruments (sensors) that provide EO data. A list of important current satellites, non-operational satellites and satellites in development (along with their sensors) is given in Supplementary Material Table S1 (which contains a list of 300 satellites, where 162 are operational, 116 non-operational, and 22 in development), based on data provided in three sources: WMO-Oscar [39], EO satellite portal [40] and CEOS [41]. The list covers the satellites' characteristics (e.g., date and lifetime, type of instrument, spectral coverage), capabilities (temporal and spatial resolution, primary mission, imaging capability, data accessibility), and main applications. The satellites and instruments in Table S1 have been selected based on three criteria:

- $\quad$ they have been or are used in a wide range of programmes in sustainable development by organisations such as GEO, ESA, NASA, JAXA, etc.

- the instruments on board the satellites have provided data for more than 6 consecutive months

- the instruments on the satellites can offer time-series data from a series of similar satellites (e.g., Landsat, Sentinel, NOAA, GOES, METEOSAT, HY).

EO satellites can be passive (measuring the light reflected from or the thermal energy emitted by the Earth) or active (measuring the interaction of energy emitted by the satellite with the Earth, e.g., through radar). Passive EO satellite sensors provide data at various spectral, spatial, and temporal resolutions. The spectral resolution refers to the wavelengths of radiation that can be detected by the instrument and, for example, in the visible and shortwave infrared regions, the information in different spectral bands can provide a spectral 'signature' for different land cover types (e.g., vegetation, soil, water, buildings). Spatial resolution (typically reported as the number of metres covered by one dimension of a single pixel) is a measure of the observable detail in an image, and modern optical sensors provide multispectral and panchromatic (PAN) imagery at much finer spatial resolutions than seen in previous decades [42] (although the chosen resolution for a modern mission is a compromise between resolution and coverage.) Different space agencies, companies, and other organizations categorise the spatial resolution of satellite images differently; thus, 'high resolution' can have a variety of meanings. In general, the categories used for images are classified as shown in Table 3. Satellite data can also be categorised by the type of orbit the satellite is in, whether it is in a high geostationary orbit (so it always observes the same locations on Earth) or in a low Earth orbit (so it tracks the surface as it orbits).

Table 3. Spatial resolution of satellites in EO [43].

\begin{tabular}{clc}
\hline \multicolumn{1}{c}{ Spatial Resolution } & \multicolumn{1}{c}{ Examples of Satellites } & Scale \\
\hline Coarse resolution $(>1000 \mathrm{~m})$ & e.g., GCOM, Envisat, Aeolus, etc. & $\begin{array}{c}\text { Global and } \\
\text { regional }\end{array}$ \\
\hline Medium resolution (100 m to 1000 m) & $\begin{array}{l}\text { e.g., MODIS, AVHRR, Sentinel-3 } \\
\text { OLCI, etc. }\end{array}$ & $\begin{array}{c}\text { Global and } \\
\text { regional }\end{array}$ \\
\hline Fine resolution (5 m to $100 \mathrm{~m})$ & $\begin{array}{l}\text { e.g., Landsat 5-8 TM, Sentinel-2, } \\
\text { SPOT 5, DMC etc., }\end{array}$ & Regional and local \\
\hline Very high resolution (VHR) $(<5 \mathrm{~m})$ & $\begin{array}{l}\text { e.g., Rapid Eye, WorldView, } \\
\text { Pleiades, SkySat, SuperView, etc. }\end{array}$ & Local \\
\hline
\end{tabular}


Free and open access data play a key role in enabling the discovery, retrieval, and manipulation of data to monitor the planet [44]. For instance, NASA and the U.S. Geological Society (USGS) have provided free Landsat imagery since 2008 [45]; ESA has released free data (e.g., ERS, Envisat, Meteosat) since 2010; now, all data from the operational Sentinel missions are freely available via the Copernicus Programme [46].

Open data can be freely used, re-used, and redistributed by anyone, whereas commercial data, such as VHR imagery from commercial satellites, require the user to purchase the data and to follow a license agreement. Commercial satellite imagery can be expensive depending on the size of the area of interest, spatial resolution and number of observation dates required. Rudd et al. [47] provided an example of using commercial satellite data for precision agriculture, as this application benefited from higher spatial and temporal resolutions than space agency sensors can provide; however, they considered these data expensive for their application. Comparisons of the cost-effectiveness of EO-derived data versus other sources of data are still relatively rare in the literature; nevertheless, examples are provided by [48-52].

The findings of these studies suggest that using EO-derived data can be more cost advantageous compared with the use of other data; however, the savings depend on the scale of the project and what other types of data are available. For example, Bruzelius et al. [52] conducted a cost-effectiveness analysis for their approach in detecting the healthcare service buildings for an area in south-eastern Liberia; the computational and data cost involved was USD 12.30; if the method was applied for the entire country, the cost would be approximately USD 141. These low prices show that EO-derived data can provide information at a substantially reduced cost compared to the traditional monitoring costs, which determines SDG indicators accessible for all nations, thus providing an opportunity for "leaving no one behind" [51].

There are numerous web portals and services that enable the discovery, access, and use of EO data and derived information products. These can be classified into three main categories:

- EO data portals

- EO processing, visualisation, and cloud computing platforms (where the term 'platform' in this paper refers to those online resources layer which provides the 'back-end' functionality of EO satellite images, rather than the engineering use of "platform" used to contrast the "satellite" with its "sensor")

- $\quad$ EO derived thematic products and services $[53,54]$

There are around $25 \mathrm{EO}$ data portals that provide free (to the user) and open satellite data at medium spatial resolution (e.g., Sentinel and Landsat) and historical VHR data (these are listed in Supplementary Material Table S2) [55-80]. Free and open access EO data are generally provided by taxpayer-funded national and international space agencies and are provided for the public good. They play a major role in expanding the spectrum of new users and applications [81]. There are numerous commercial suppliers (e.g., PlanetLab, Maxar Technologies, Iceye, Earth-I, EarthBlox, Pixera, Surrey Satellite Technologies, etc.) that offer EO satellite data and/or products for a cost or a subscription plan tailored to the clients' needs.

EO processing and visualisation platforms provide images that have passed through several 'levels' of processing, integration, and analysis of raw EO data. Corrections at these levels include radiometric calibration, atmospheric correction, and the derivation of products from the satellite data (such as land classification maps); these EO-based products are often further processed and combined with other geo-referenced socio-demographic, economic and environmental data. The new cloud-based infrastructure services are becoming more important as they enable users to access, store, and analyse large volumes of EO data without having to download (and in some cases process) the raw data [53,81]. These cloud platforms provide 'analysis ready data' (ARD) which are normally geometric, orthorectified and radiometrically calibrated [24]. They can include integrated technologies such as application programming interfaces (API) and web services to provide a more 
complete solution for big EO data management and analysis. Currently, there are around 14 major platforms that include big EO data management and analysis which offer mainly free data access with commercial infrastructure, but use different storage systems, and access interfaces of large EO data sets (listed in Supplementary Material Table S3) [53]. Among these platforms, Google Earth Engine (GEE) combines a multi-petabyte catalogue of satellite imagery and geospatial datasets with planetary-scale analytical capabilities and is available for scientists, researchers and developers to detect changes, map trends, and to quantify differences on the Earth's surface [28]. However, one barrier to the use of such platforms is the need for computing skills and facilities to download and manipulate large datasets.

In terms of EO-derived thematic products and services, ESA, NASA, and other partners have created dedicated portals with advanced visualisation tools and services where users can directly access spectral indices such as NDVI, as well as products derived using advanced and complex algorithms that assess land degradation, land cover change, water quality, etc. These free-to-the-user higher-level products require less expertise to manipulate the EO data and generate products but are more susceptible to data misinterpretation as a result of accessibility with a lower expertise level. These products provide quantitative data to develop a baseline, assess trends, and address SDG indicators (a selected list of these thematic products is presented in Table S4) [82-88].

Such portals and platforms integrated with big data provide several benefits, as they provide a consistent, standardised product that has been developed by experts, that can be used by a wide range of users without those users needing an expert understanding (of the instruments) but lead to greater misinterpretation with assumptions made about the sensor performance $[89,90]$. One of the first systematic data cubes to be established was the Australian Geoscience Data Cube [91], which provides standardised data in a common format on a range of processing platforms and with common pre-processing. These analysis-ready data initiatives have great potential for NSOs; however, there has not yet been the investment to establish how best to use the data at the national level [24]. There can also be a misconception that such data can be considered reliable simply due to the volume of data available; however, this is not necessarily the case [24]. Efforts are being made through satellite communities such as CEOS CARD4L [92] to provide some consistent validation and evaluation of such products, although those initiatives are still at an early stage and quality statements should be cautiously interpreted.

It is critical for users of EO information to understand and consider the key characteristics (spectral, temporal, and spatial resolutions, and calibration uncertainties) of the satellites and their applications to determine which are the most suitable to address specific needs $[37,93,94]$. Some applications require data over relatively short periods such as monitoring oil spills [95], forest fires [96], and sea ice motion [97], while, for understanding long term trends of environmental and climatological issues, long time series of images, and multi-decadal stability of the data set, which implies radiometric accuracy, are essential [97]. Other applications are in between, needing seasonal imaging especially for crop identification [98], phenology [99], and wetland monitoring [100]. Table 4 illustrates a representative range of $\mathrm{EO}$ applications with strong relevance to various aspects of sustainable development, although it should be noted that this is by no means an exhaustive list. 
Table 4. Example EO satellite applications with relevance to the SDGs.

\begin{tabular}{|c|c|c|}
\hline Main Application & Classification & Example EO Applications \\
\hline \multirow{4}{*}{ Environmental } & Terrestrial & $\begin{array}{c}\text { Land use and cover change [85] } \\
\text { Biodiversity and habitat assessment [101,102] } \\
\text { Inland water resources [103] } \\
\text { Forestry- Deforestation and Afforestation [104] } \\
\text { Reforestation [99] } \\
\text { Forest fire [105] } \\
\text { Agriculture (crop mapping) [98] } \\
\text { Hydrology [106] } \\
\text { Mining and mineral exploitation [107] } \\
\text { Species growth (phenology) [108] } \\
\text { Soil Moisture [109] } \\
\text { Soil organic carbon [110] } \\
\text { Snow cover and glaciers [111] } \\
\text { Species identification [112] }\end{array}$ \\
\hline & Ocean & $\begin{array}{c}\text { Sea-surface temperatures [113] } \\
\text { Ocean colour and algae blooming [114] } \\
\text { Sea levels [115] } \\
\text { Algae blooming [116] } \\
\text { Floating plastics [117] } \\
\text { Sea-Ice [97] } \\
\text { Marine and coastal environments [118] } \\
\text { Species identification [119] }\end{array}$ \\
\hline & Atmospheric & $\begin{array}{c}\text { Weather forecasting [120] } \\
\text { Radiation, evapotranspiration [121] }\end{array}$ \\
\hline & Climate system & $\begin{array}{c}\text { Air quality and greenhouses gases [122] } \\
\text { Carbon Dioxide [123] } \\
\text { Ozone [124] } \\
\text { Nitrogen dioxide [125] } \\
\text { Methane [126] } \\
\text { Nitrogen dioxide [127] } \\
\text { Sulphur dioxide [128] }\end{array}$ \\
\hline \multirow{7}{*}{ Socio-economic } & Disaster management & $\begin{array}{c}\text { Oil spill [95] } \\
\text { Disaster risk and damage assessment [129] } \\
\text { Geohazard risks [130] } \\
\text { Flooding [131] }\end{array}$ \\
\hline & Corruption & $\begin{array}{c}\text { Illegal logging [132] } \\
\text { Favouritism [133] } \\
\text { Illegal fisheries [134] } \\
\text { Inflated GDP [135] }\end{array}$ \\
\hline & Transport & $\begin{array}{l}\text { Ship tracking [136] } \\
\text { Transportation infrastructure [137] } \\
\text { Smart transport and logistics [138] }\end{array}$ \\
\hline & $\begin{array}{l}\text { Socio-Economic } \\
\text { development }\end{array}$ & $\begin{array}{c}\text { Global population density [139] } \\
\text { Quality of life [140] } \\
\text { Ethnic minorities development index [141] } \\
\text { Poverty [142] } \\
\text { Economic growth and GDP estimation socio-economic } \\
\text { activities [143] } \\
\text { Urbanisation dynamics [144] } \\
\text { Regional inequality [145] } \\
\text { Urban planning [146] }\end{array}$ \\
\hline & Energy & $\begin{array}{c}\text { Electricity consumption [147] } \\
\text { Access to electricity [148] }\end{array}$ \\
\hline & Humanitarian & $\begin{array}{l}\text { Human rights [149] } \\
\text { Natural disasters, structural damage assessment, and } \\
\text { population estimation in settlements in conflict [150] } \\
\text { Forced labor [151] }\end{array}$ \\
\hline & Health & $\begin{array}{l}\text { Incidence of breast cancer [152] } \\
\text { Response for Vector-Borne Diseases [153] } \\
\text { Access to health services [52] }\end{array}$ \\
\hline
\end{tabular}

Several peer-reviewed articles and case studies published since 2017 have explored the contribution of satellite imagery towards the SDG indicators and targets $[14,15,27,35,36$, 90,154-158]. Some examples are provided in Table 5. 
Table 5. Published assessments of EO data use in support of SDG indicators and targets.

\begin{tabular}{|c|c|c|c|}
\hline Title & Type & Year & EO Data Contribution on SDG Indicators \\
\hline $\begin{array}{l}\text { Earth observation in service of the } \\
2030 \text { Agenda for Sustainable } \\
\text { Development [154] }\end{array}$ & Peer review & 2017 & $\begin{array}{l}\text { First review of the EO contribution for SDGs, } \\
\text { focusing on the role of GEO and GEOSS work } \\
\text { and the actual use of EO in support of the SDGs. } \\
\text { Presents the major GEO projects that address } \\
\text { indicators from SDG 2, SDG 6, SDG 15. Also, it } \\
\text { discussed the importance of capacity building, } \\
\text { data access, and global collaboration with NSOs } \\
\text { and custodian agencies. }\end{array}$ \\
\hline
\end{tabular}

Satellite Earth Observation in support

2018 data for several indicators that cover SDG 2, of the Sustainable Development Goals [36]

EO4SDGs Initiative [27]

SDG 6, SDG 11, SDG 14, and SDG 15.

\section{Report}

(

EO4SDGs Initiative is launching a series of pilot projects to apply and test uses of EO to support the assessment and tracking of the SDGs, including integration with national statistical accounts for the indicators.

MMF 1.0 is an analytical framework that is based on 3 premises (methods of processing EO data, requirement of non-EO information, and level of completeness). A total of 80 peer reviews and reports were systematically reviewed under

Maturity Matrix Framework (MMF) 1.0 [14]
Framework

2018 MMF 1.0 to seek the potential of EO data to support SDG indicators. The MMF 1.0 was applied to all SDG indicators and found 84 indicators that were classified into three categories: weak support from EO, indirect measure by EO data and high potential of EO data directly to populate the SDG indicator.

MMF 2.0 is similar to the previous framework,

Maturity Matrix Framework (MMF) $2.0[15]$

A Review of the Sustainability

Concept and the State of SDG Monitoring Using Remote Sensing [157] contributions to the SDG Targets and Indicators [156]
Compendium of Earth Observation
Compendium/Framework 2020
Framework

Review but it evolved into 6 premises after expert interviews were conducted with 38 specialists in EO and sustainability.

The scope of this review was to summarise the work and best practices of using $\mathrm{EO}$ for supporting the SDG indicators.

ESA Compendium presents case studies of using EO satellite-derived data for a total of 34 indicators which were assessed against a framework that discriminates the indicators into two categories; 17 indicators can be directly measured, and 17 indicators indirectly informed by EO data across 29 targets and 11 goals.

EnviroAtlas is a web-based, interactive map of environmental and socio-economic data relevant to the SDGs. It provides multi-resolution spatial

EnviroAtlas [35]

Review

2020 indicators and introduced proxy indicators related to the SDGs.

The paper presents multiple examples of using EO for 47 targets across most goals.

Maxar company (formerly known as DigitalGlobe) [158]
Review

The report summarised the case studies that address all SDGs. 
GEO and its space-agency arm CEOS has set out how EO can support the SDG indicators through their EO4SDG initiative [154]; more recently, they have published a report detailing the achievements of the programme, examples of application and further steps [155]. In particular, they noted successes in collaboration with UNEP in assessing SDG Indicators 6.6.1 (spatial extent of water-related ecosystems) and 6.3.2 (ambient water quality), with UNCCD on Indicator 15.3.1 (proportion of degraded land per total land), and with the UN Habitat on Indicator 11.7.1 (average share of the built-up area of cities that is open space for public use) which enabled these four indicators to be recognised as conceptually clear with internationally accepted methodologies. GEO suggests that EO data have a role to play in monitoring progress with 71 out of the 169 Targets and 30 out of the 232 indicators either directly or indirectly [154,155].

More recently, as part of the GEO EO4SDG initiative, in collaboration with the ESA, an analysis has been completed regarding the contribution of EO for the Global Indicator Framework [156]. In this analysis, the authors sought to identify those indicators where EO could reasonably contribute to the development or implementation of indicator methodology and based this on two main criteria which they refer to as "readiness" and "adequacy". A "traffic light" system of red, amber, and green colours was then applied across a suite of 34 selected indicators to flag EO relevance.

A further example of an analysis of the potential of EO for the SDG indicators is provided by EnviroAtlas, developed by the United States Environmental Protection Agency and other partners. EnviroAtlas provides a collection of web-based, interactive maps of environmental and socio-economic data that support numerous SDG targets and indicators that cover goals $6,11,15$ and 4 .

The increasing trend of launching constellations of nano and microsatellites (operates between 60 and 100 small satellites) into space has been clear and well established in the last two decades, aiming for higher spatial resolution and near real-time measurements and continuous monitoring due to the daily revisit times [159]. In addition, there is an increasing willingness to a partnership between the EO companies and custodian agencies exploring the use of EO data to address SDGs. For instance, Planet Labs is working with UN agencies, Kongsberg Satellite Services (KSAT) and Airbus to help measure the SDG indicators by offering free access to VHR satellite, $(<5 \mathrm{~m})$ for 64 countries involved in monitoring tropical rainforests. This partnership also helped support an interactive platform called "Global Forest Watch", (an open-source web application that monitors global forests in near real-time) [160].

Another example of an EO company engaging with the SDGs is the Maxar company [158]. Engstrom et al. [161] investigated whether high-resolution satellite imagery from Maxar Technology can accurately and affordably estimate the economic well-being of 1291 Sri Lankan villages from space using machine learning and VHR imagery focused on proxy indicators, such as car counts, building density, green space, and more, which have all been used in models to predict the spatial variability of poverty across urban areas. Maxar VHR satellite data have also been used to map areas at high risk for malaria, based on population density and proximity to standing water. This has helped health workers determine the required number of life-saving mosquito nets and the exact locations to use insecticides [162]. Another example is the use of EO and mobile phone data to help understand the disparity in transportation use by gender and the role it plays in inequality (SDG 5) in Santiago, Chile. The GovLab and its partners DigitalGlobe, UNICEF together with other organisations, established the first-ever baseline study of the urban mobility experiences of women and girls, in which VHR satellite data play a role in human mobility patterns [163-165].

Among many case studies that address the more environmental SDGs, ESA presented an example using satellite data and algorithms targeted at detecting illegal waste sites [36,166]. They identified 207 sites classified as suspicious across one test area of 7000 $\mathrm{km}^{2}$ in the UK [167]. These sites are often associated with lower income and high-rate crime areas and, thus, can help address indicators within SDG targets 12.4, 6.3 and 11.6 [36]. 


\section{Assessing EO Contribution to SDGs Indicators Using a Maturity Matrix Framework (MMF) Approach}

In 2017 and 2019, Andries et al. [14,15] presented analyses of published literature and other reports on the applicability of EO satellite data for SDG indicators using a structured MMF based on six premises (uncertainty assessment, directness, completeness, requirement for non-EO information, practicability, and cost-effectiveness analysis). The indicators were allocated an aggregate assessment score (entitled Maturity Matrix Score (MMS)) based on the premises detailed in [15] and their overall potential for being populated with data from EO sources. Two versions of the MMF framework were produced and, using the latest version (MMF 2.0), applied to all 232 SDG indicators some 80 of them were determined to have some potential for being populated with data by EO. Of these, EO was found to provide weak support (MMS between 1 and 2) for 25 indicators, partial support (MMS values between 2 and 4 ) for 40 and strong support (MMS values between 4 and 5) for 15 indicators. The remaining 152 indicators had no evidence that EO could be used (at the time of the research).

The SDG indicators have not been formally classified in terms of the three pillars of sustainability (economic, social, and environmental) by the IAEG-SDGs; there have been, perhaps surprisingly, few attempts to do this reported in the literature. Some exceptions are provided by Paoli and Addeo [168] on the SDGs, Tremblay et al. [169] for the SDG targets and Cochran et al. [35] for the SDG indicators. Such a classification of indicators can be useful from a policy point of view [170] and can help to identify priorities for early action, understand implementation challenges, detect data gaps and indicate the trade-offs among SDGs [168].

A widely used taxonomy of indicators is based on the three pillars of sustainability that includes environmental, economic and social indicators (sometimes institutions are listed as a fourth dimension) [171]. Social indicators deal with broad categorical concerns of well-being (e.g., OECD's survey “How is life?" [172]), values (e.g., human values [173]), agency (demographic and health surveys [174] and inequality (often calculated via Gini coefficients) [175]). Economic indicators are statistics that allow an analysis of the economic performance of a country and are classified into two main categories: economic structure (e.g., gross domestic product (GDP), investment share in GDP, the balance of trade in goods and services) and consumption and production patterns (e.g., consumer price index (CPI), producer price index (PPI), household consumption, etc.) [171]. Environmental indicators are based on the four main Earth systems: atmosphere, hydrosphere, lithosphere, biosphere. Some environmental indicators are based on the human (anthropogenic) impact on the four main Earth spheres. The processes of human interaction and the Earth-system response to that interaction, such as pollution flows and natural resources stock (e.g., greenhouse gas emissions- $\mathrm{CO}_{2}, \mathrm{SO}_{\mathrm{x}}, \mathrm{NO}_{\mathrm{x}}$, methane), use of water resources, river quality, wastewater treatment, land-use changes, protected areas, use of nitrogenous fertilizers, use of forest resources, trade in tropical wood, threatened species, fish catches, waste generation, municipal waste, industrial accidents). Lastly, partnership indicators measure the effectiveness of cooperation between two or more organisations [176].

The authors classified the SDG indicators into five main categories, as follows: social, economic, environmental, the comprehensive indicators-socio-economic and socioenvironmental - and partnership; the results are presented in Figure 2. The assessment resulted in 94 social indicators that mainly related to social inclusion and inequality reduction (SDG 5 and SDG 10), poverty eradication (SDG 1), quality education (SDG 4), sustaining good health and well-being (SDG 3), and promoting peaceful and inclusive societies (SDG 16). There are 14 economic indicators mostly represented by GDP (in its various forms) that can be found in SDG 2, SDG 8, and SDG 10. There are 27 SDG environmental indicators that encompass issues of water scarcity, water resource management (SDG 6), climate change (SDG 13), loss and degradation of biodiversity and ecosystems services (SDG 6, SDG 13, SDG 14, SDG 15), deforestation (SDG 15). Most partnership indicators (14 out of 16) occur in SDG 17, as the goal focuses on progress made in strengthening 
global partnership and in improving financial governance. The last category, comprehensive SDG indicators, cover 96 indicators, of which 30 have socio-environmental features and 66 include socio-economic dimensions of sustainability. Therefore, the SDG indicator framework has an imbalance across the three pillars of sustainability and is mainly focused on the socio-economic aspects with only 27 environmental and 30 socio-environmental indicators.

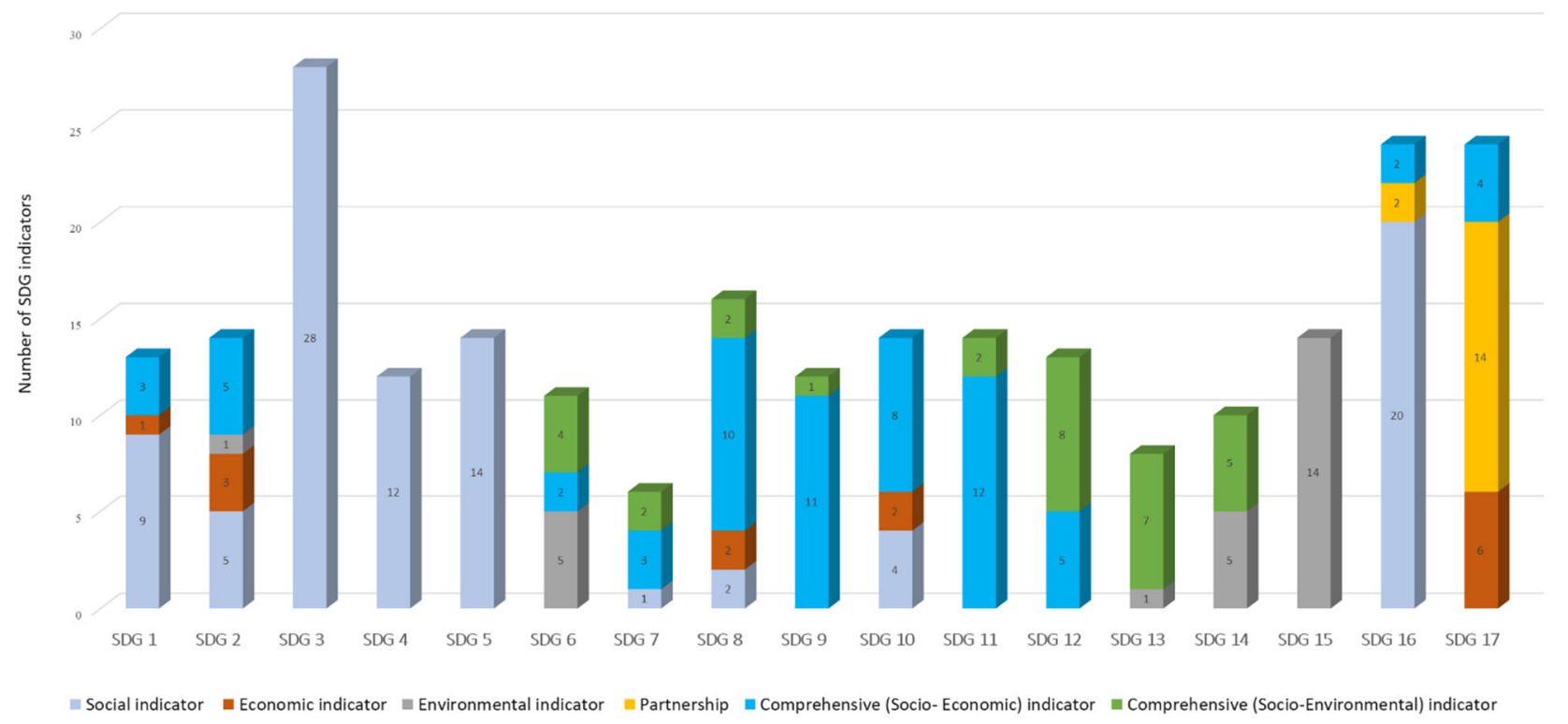

Figure 2. SDG Indicator type based on the three dimensions of sustainability (Authors' assessment).

Based on the MMF 2.0 [15] summarised above, we have re-evaluated all SDG indicators using the latest best practice case studies and approaches available in the literature and reports up to mid-2021 and have applied the categories presented in Figure 2. The results (see Figure S1) suggest that 108 SDG indicators could be populated, at least in part, by using data from EO. These comprise 19 indicators with weak support from EO, 67 with partial support from EO, and 22 with strong EO support. The remaining 139 indicators had no evidence (yet) (see Figure 3) that EO data could be used for their support; however, this is a rapidly evolving field in which future approaches to using EO data for social indicators may be developed.

These results have been sorted further in Figure 3, based on the indicator types of Figure 2. The findings suggest that a strong contribution of EO data is predominantly within the environmental type indicators; however, that was not exclusive, as several social-economic indicators (e.g., indicators 1.4.2, 1.5.1, 1.5.2., 2.1.1, 11.5.1, 11.6.2) can be also measured directly by EO data. For instance, indicator 1.5.2. (direct economic loss attributed to disasters in relation to global GDP) can be directly measured by EO datasets; Pham et al. [177] have shown an approach of automatic detection of building damage of an earthquake, and EO optical and radar imagery can be used to gather useful information on the economic loss on other disasters (e.g., flooding, transport infrastructure, fires, landslides, etc.) at different stages. Satellite data of very high spatial and temporal resolutions play a critical role in disaster management. 


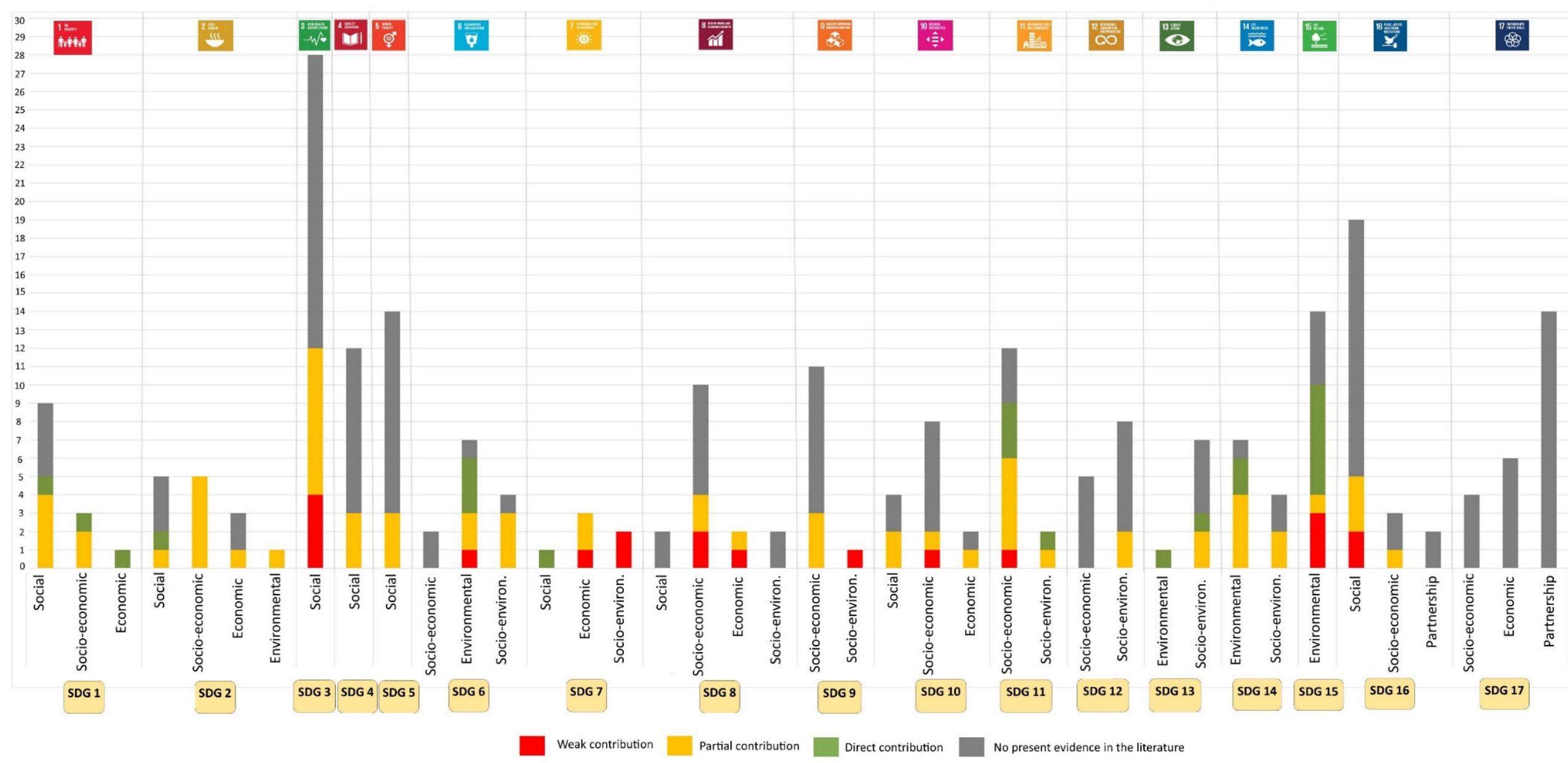

Figure 3. SDG indicators type and the EO satellite contribution (based on MMF 2.0) (Authors' assessment). 
Moreover, indicators with partial support from EO are spread amongst all indicator types, reflecting the potential of EO satellite-derived data to play a role in calculating the SDG indicator via a proxy indicator. For example, SDG indicators 16.1.1 (number of victims of intentional homicide per 100,000 population, by sex and age) cannot be measured directly by satellite data. However, Patino et al. [178] investigated the influence of the urban layout (e.g., impervious surface percentage, type of roofs, land cover types) on homicide rates using VHR image and integrated census data for socio-economic variables; thus, they found associations of higher homicide rates with more heterogeneous and disordered urban layouts. Likewise, EO data have been used to monitor conflicts (bombing, military presence, war) by using historical records of the areas that changed over time and humanitarian efforts, for example, by spotting refugee camps and estimating the number of refugees from space [149]; all these applications can be linked to SDG indicator 16.1.2 (conflict-related deaths per 100,000 population, by sex, age and cause).

A weak contribution of EO data to supporting the indicators occurs primarily among indicators within the more socio-economic category. By its nature, SDG indicator 8.3.1 (proportion of informal employment in total employment, by sector and sex) cannot be supported directly by EO data; nevertheless, Ghosh et al. [179] explored the potential for estimating the formal and informal economy for Mexico using known relationships between the spatial patterns of nighttime satellite imagery and economic activity. They developed regression models between spatial patterns of nighttime imagery and adjusted official gross state product (AGSP) for the USA states. These regression parameters derived from the regression models of the USA were 'blindly' applied to Mexico to estimate the estimated gross state income (EGSI) at the sub-national level and the estimated gross domestic income (EGDI) at the national level. Comparison of the EGDI estimate of Mexico against the official gross national income (GNI) estimates suggested that the magnitude of Mexico's informal economy and the inflow of remittances are 150\% larger than their existing official estimates in the GNI.

Comparison of the MMF results from 2019 to 2021 (see Supplementary Material Figures S1 and S2) reveals 30 new indicators over these approx. 2 years where there is published evidence that EO can provide some support. This suggests that researchers are increasingly finding ways to use EO data in social and economic indicators. It also reflects the amendments agreed by IAEG-SDG in December 2020 that introduced new indicators and revised or removed others.

Figure 4 illustrates these 30 indicators with new EO-based methods, categorised into their type and role of the EO contributions. Many of the social indicators that have new EO-based methods are related to education. For instance, in one of the new approaches, Yazdani et al. [180] noted that EO data can provide appropriate reliability, accuracy, and convenience for identifying rural schools in Liberia via machine learning approaches; based on their approach, UNICEF [181] launched an initiative to map every school in the world, thus contributing to achieving SDG 4 (quality education). In addition, the usage of night-time satellite data can help monitor aspects of education facilities, such as access to electricity [182,183] and drinking water [184], which are closely linked to SDG 4.a.1 indicator (schools with basic service as electricity and internet). Furthermore, Andries et al. [185] used VHR satellite data and enrolment data to calculate the primary school classroom area per pupil in rural Nigeria. They found that over $70 \%$ of the 1900 schools evaluated could be classified as overcrowded (according to Nigerian government metrics), this being highly correlated with poverty and literacy rates. Andries et al. [185] also analysed their area per pupil result via the MMF approach, which characterised this EO support as partial for the SDG indicators 4.1.2. (Completion rate in primary education, lower secondary education, upper secondary education) and 4.6.1 (Proportion of population in each age group achieving at least a fixed level of proficiency in functional (a) literacy and (b) numeracy skills, by sex). While area per pupil is not an SDG indicator, it potentially provides a useful contribution since overcrowded schools influence SDG indicators, such as completion of primary education and absenteeism, and can lead to low literacy and 
numeracy rates. The study is a proof of concept that was further validated in situ by Andries et al. [186].

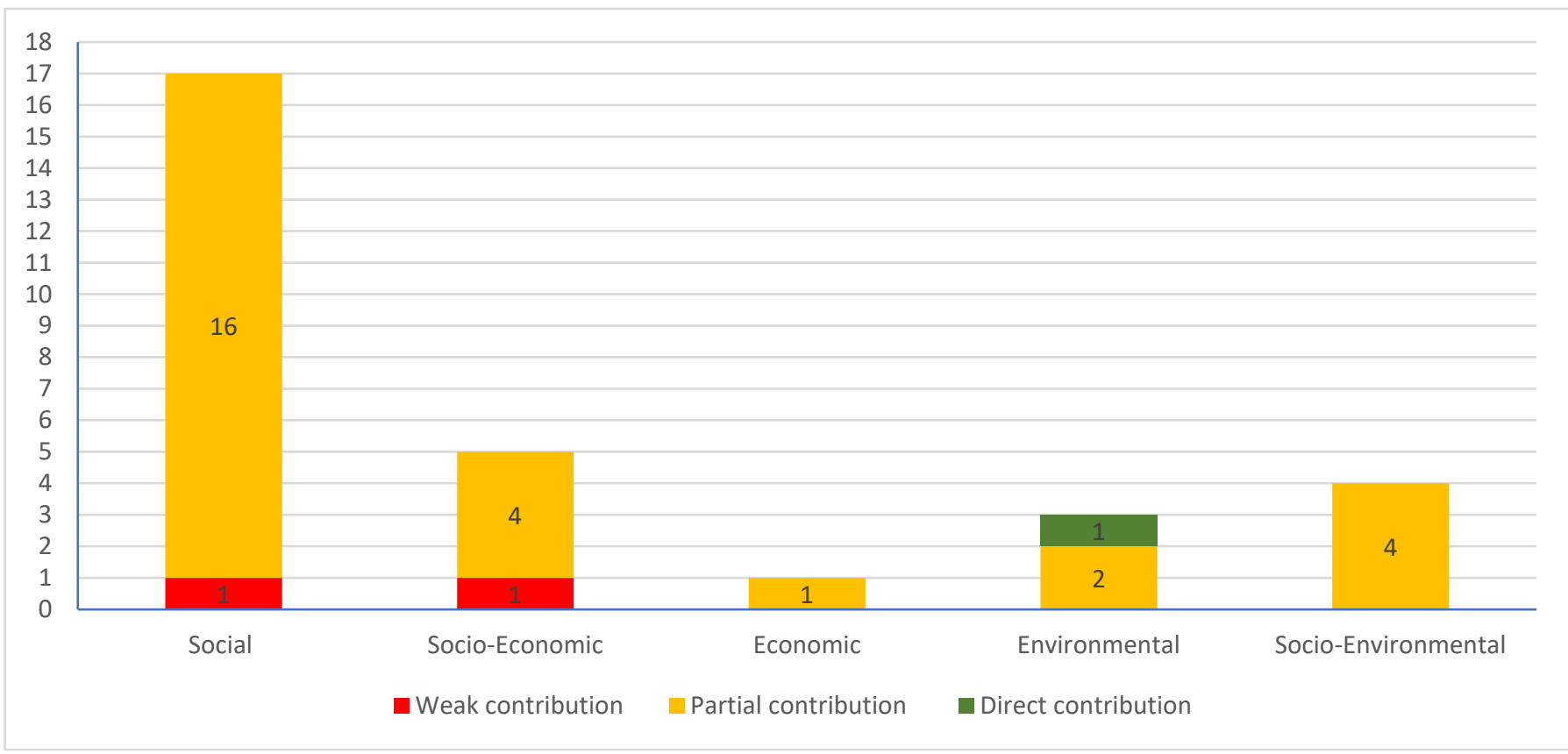

Figure 4. EO contributions for SDG indicators against the MMF 2.0 and the latest publications (Authors' assessment).

The good health and well-being goal (SDG 3) is another social goal where new methods have been derived to evaluate indicators using EO data [187-189]. For example, Bruzelius et al. [52] used EO images and machine learning to assess health services in remote villages, thus providing information that partially contributes to indicator 3.8.1 (coverage of essential health services).

The latest developments in satellites continue to help to support the more environmentalbased SDG indicators. One of the latest SDG indicators introduced at the IAEG-SDG December 2020 update [5] is 13.2.2 (total greenhouse gas emissions per year). EO data can help validate or complement this indicator through the wide availability of satellites; however, EO is not currently discussed in the methodological guidelines [190]. Satellites (e.g., Gases Observing Satellite (GOSAT), Orbiting Carbon Observatory-2 (OCO-2), TanSat) have been used to measure atmospheric column-averaged concentrations of the key greenhouse gases $\mathrm{CO}_{2}$ and $\mathrm{CH}_{4}$ at the global level. These can be used to complement the current methods, using flux inversions to provide estimates of natural fluxes of $\mathrm{CO}_{2}$ and $\mathrm{CH}_{4}$. ESA's Greenhouse Gases Climate Change Initiative [191] has created consistent and quality-assured products with rigorous uncertainty analysis based on these satellites, which are available via the Copernicus Climate Data Store [192]. More recent public (e.g., Sentinel 5P) [193,194] and private (e.g., GHGSat) [126,195] missions provide more detailed spatial information and can begin the process of determining emission fluxes (rather than concentrations of mixed gases) for the larger emissions (city air pollution and oil and gas fugitive emissions) [196,197]. Therefore, the current data from these satellites can be translated into actionable information to achieve the goals of COP 26 and SDG 13 (climate action) [198]. Furthermore, there are new missions in development that will further increase our understanding and direct monitoring of GHG emissions (e.g., Microcarb). An area of current research is the exploration of the potential of other medium and high resolution platforms, not initially designed for atmospheric retrievals, such as Sentinel 2, PRISMA, WorldView-3, to fill the spatial and temporal gaps in mapping methane plumes from point emitters [197]. 
As can be seen in Supplementary Material Figure S2, 11 indicators that had weak support from EO, have 'upgraded' to providing partial or strong support from EO due to new publications with new EO-based methods. For instance, indicator 7.1.1 (proportion of population with access to electricity) had an MMS of 2.5 (amber) in the original MMF 2.0 dashboard analysis, based on the project India Lights [199]. This project was a collaboration between Development Seed, the World Bank and the University of Michigan that used the DMSP images to extract the light output of individual villages to show those that had access to electricity. However, in this latest review, we increased this indicator's MMS score from 2.5 (amber) to 4 (green) based on a joint project (by Facebook, The Energy Sector Management Assistance Program (ESMAP) at the World Bank, the KTH Royal Institute of Technology, the World Resources Institute (WRI), and the University of Massachusetts Amherst) that developed a predictive model for mapping medium-voltage distribution using night-time satellite data, a MODIS land cover dataset and geospatial products (e.g., different type of roads, railways, political boundaries). The increased score came from the new work on assessing uncertainty (with more validation against ground-truth data) and improved practicability premises (with the method now integrated into the end-user's decision-making in several countries [200] with the possibility to replicate the model (using the model documentation and codes) to other countries [201].

\section{Discussion}

The SDG framework, with its targets and indicators, stands as the most comprehensive, universal, and ambitious plan to end poverty, promote prosperity and people's well-being and protect the environment, and has been agreed to by 193 world leaders spanning the developed and developing worlds. The achievement of the SDGs relies prominently on the availability and use of relevant, reliable, and timely data to measure progress, inform policies and target those areas that need improvement. Traditional data sources have administrative and technical limitations, in terms of data access, standardisation and quality, lack of awareness concerning the benefits of current technologies, lack of financial resources, technology and skills gaps, geographical constraints (in terms of developing space projects), and coverage gaps across space and time [202]. Indeed, surveys suggest that $73 \%$ of countries require assistance to upgrade existing data sources [203]. Thus, the world is currently not on track in terms of being able to populate the SDG indicators; only $44 \%$ of the SDG indicators have sufficient data for global monitoring. However, the advent of new EO technologies, either by themselves or combined with traditional data sources and methods, offers the opportunity to provide robust and timely data on a routine basis for monitoring and decision-making that supports the achievement of the SDGs.

Given a large number of satellites/instruments and their capabilities (spatial, spectral and temporal resolution) (Table S1), free and open access portals (Table S2), data cubes (Table S3), and EO thematic platforms (Table S4), there is potential to monitor every place on Earth. EO data can help save time and cost [204,205] compared to the generally more labourintensive traditional approaches. There are some common misconceptions related to the economic cost of VHR [206,207]; performing cost-effectiveness analysis can help identify the most effective and competitive data [208,209]. For instance, Watmough et al. [51] examined the role of using satellite data to assess the household wealth by considering the spatial landscape use, size of the building, agricultural productivity, land use and cover surrounding the household as predictor variables. They also estimated the price for traditional and EO analyses. Surveying 330 households in rural areas of western Kenya would cost USD 106,500 per year, compared with USD 1750 to USD 5000 per year for 100 $\mathrm{km}^{2}$ (covering the same 330 households) using VHR satellite data. They demonstrated that satellite data can predict household wealth with $62 \%$ accuracy compared with the traditional sampling methods and suggest that EO data be used to understand the dynamics of changes in wealth between less frequent household surveys.

Nevertheless, there are capacity issues within NSOs that need to be addressed to enable access to and use of EO data. These issues are not only about providing training 
to NSO staff, but also about the strategic direction in the political agreement process and cooperation between geospatial and EO communities, organisations, ministries, and stakeholders. Likewise, there is a need for investment in the official statistics community in terms of EO data manipulation,interpretation, and digitalisation.

This issue can be resolved by increasing technical capacity and infrastructure, but also via regulations designed to build and consolidate trust among different stakeholders involved in data sharing. Since 2015, GEO and its initiative EO4SDG, custodian agencies and academia increased their efforts to explore the potential of EO and geospatial data to support SDG indicators and targets; thus, in the last couple of years, there have been several reviews that assess the EO contributions for SDG indicators under various frameworks and analyses alongside practical guidance [14,15,27,35,36,90,154-158]. Despite these developments, some countries are reluctant adopters for several reasons, such as concerns about satellite data "spying" and confidentially, or because of a lack of data standardisation and/or because they do not yet have the technical and infrastructure capacity in using EO data [210]. Notwithstanding such reluctance, there are several examples of fruitful collaborations between country NSOs and geospatial agencies, such as the case of Ireland, Sweden, South Africa, Colombia, the Philippines, and the UK that integrated EO and/or geospatial data for indicators that cover SDG 6, 11, 13 and 15.

In this paper, the framework developed by Andries et al. [15] was applied to the most recent publications (up to June 2021), updating a similar analysis presented in the earlier paper. Interestingly, rapid progress in terms of the EO data usage for supporting the SDG indicators has occurred in the last 3 years, revealing an additional 30 SDG indicators that can be measured by EO data (mostly through an indirect approach), with 26 of these indicators having socio-economic features. This rapid progress in the most recent years is likely driven by the increased availability of open source data, the collaboration between various organisations, including the commercial sector, academia and GEO and other organisations that continue to provide efforts promoting this type of data at the Statistical Geospatial Integration Forum [211] and other relevant events [212].

However, there remain 139 SDG indicators for which there is currently no EO support. When classifying the SDG indicators based on their sustainability pillars in the present research, we observed that $174(71 \%)$ of the SDG indicators are strongly oriented towards social or economic pillars, which implies some barriers in the use of EO data for indicators in those categories.

Likewise, we considered it valuable to classify the SDG indicators with regard to the well-established Driver-Pressure-State-Impact-Response (DPSIR) analysis [213-215] (a framework that describes the interactions between society, environment, and socioeconomic outcomes) as a further perspective on the components of the SDG that can be monitored using EO data. This classification has been performed by Andries et al. [216] and Masó et al. [217], and both found an uneven distribution of the SDG indicators into the five DPSIR components, with a large percentage of response and state indicators $(32 \%$ and $41 \%$ respectively), followed by impact $(18 \%)$, driving forces $(6 \%)$ and $3 \%$ for pressure indicators.

Response indicators cannot be measured directly by EO and can only rarely be assessed via proxy indicators. As an example, consider the response indicator SDG indicator 14.6.1 (degree of implementation of international instruments aiming to combat illegal, unreported and unregulated fishing). This indicator monitors the human action (the response), i.e., whether countries are enforcing international agreements about illegal fishing through management strategies, regulations and policies. EO data can support the overall aims behind this indicator through an indirect approach, as satellites sensors can monitor maritime traffic at night using ship lighting and, thus, implicitly observe fishing activities [136,218,219]. When illegal fishing is spotted from space, as Park et al. [209] have shown in their study, this would reflect poor governance and legislation in those countries (thus this is an indirect observation of the response indicator). 
Earth observation (EO) could have the highest contributions (based on the wide variety of satellite sensors and capabilities) on the environmental SDG 15 (life on land). However, even here, (as shown in Figure S1) four indicators, 15.6.1 (number of countries that have adopted legislative, administrative and policy frameworks to ensure fair and equitable sharing of benefits), 15.8.1 (proportion of countries adopting relevant national legislation and adequately resourcing the prevention or control of invasive alien species), 15.a.1 ((a) official development assistance on conservation and sustainable use of biodiversity, and (b) revenue generated and finance mobilized from biodiversity-relevant economic instruments) and 15.b.1 (same as 15.a.1), cannot be supported by EO data due to their nature of the human decisions to the changes. On the other hand, pressure indicators on the environment such as wildfires, illegal logging, pollution, land-use change, light pollution, urbanisation, are readily measurable by EO; however, they are not covered in the SDG framework.

Therefore, the ability of EO data to support the existing SDG indicators is affected by the socioeconomic nature of the SDGs framework and by the conception and formulation of the indicators. At the same time, EO data can bring to the SDGs framework new opportunities which have not been yet explored and new indicators not yet listed in the formal system, but which could have applicability to help address the SDG targets. As Bell and Morse [220] have highlighted, an indicator must be measurable in the sense that data must be available at the required quality, spatial relevance and timeliness; such data must also be cost-effective. In this vein, Masó et al. [217] and Cochran et al. [35] have proposed new indicators that are deliberately EO based and that can complement the existing indicators, providing valuable data that is currently missing.

The UN and custodian agencies, GEO, researcher communities, and other stakeholders should take the opportunity to work together to create new or adapted indicators that optimise the use of the available data such as from EO. Much needs to be done; however, the potential of EO-derived data for populating the SDG indicators is here and is growing. Further research, exploration and examples of applications will help to expand this frontier of possibilities.

\section{Conclusions}

This paper presents the data challenges for monitoring the SDGs and how EO satellite data have been used by different communities to support the SDGs and their indicators. It has analysed the contribution of EO data from assessments carried out by various organisations and the classification of the SDG indicators based on the three pillars of sustainability. We have drawn the following main conclusions from this:

- To achieve the SDGs, inform policies and investment decisions, high-quality data (relevant, timely, reliable, and internationally comparable) for measurement and validation are needed.

- Indicators require good quality data: the lack of data and/or outdated data, particularly in developing countries, is a major constraint for monitoring the SDGs.

- Traditional data can be expensive and come with other disadvantages: new technologies, including satellite EO data and methods, can play a major role in the provision of data for many SDG indicators.

- $\quad$ The plethora of satellites now observing the Earth provides data at different resolutions and capabilities that have been used in many applications related to sustainable development, including in populating the SDG indicators.

- The framework of SDG indicators has an imbalance between the three pillars of sustainability and is mainly focused on the socio-economic aspects of sustainability, with only 27 environmental and 30 socio-environmental indicators out of its total of 231 unique indicators. The framework is also biased towards the "state" and "response" indicators of the DPSIR framework.

- $\quad$ Satellite data can be used as indirect support for many SDG indicators and has greater potential to support the SDGs beyond the existing indicators. 
- Despite the efforts of various organisations in developing satellite open access platforms (e.g., data cube, EO portals and visualisation platforms), there are still constraints to using these data and services. Furthermore, NSOs in many/several developed countries are constrained in making use of EO data for populating their SDG indicators.

Supplementary Materials: The following are available online at https:/ /www.mdpi.com/article/10 .3390/su14031191/s1, Figure S1: MMF 2.0 Dashboard (version 2019); Figure S2: MMF 2.0 Dashboard (version 2021); Table S1: List of satellites and their characteristics; Table S2: Free satellite imagery platform sources; Table S3: Platforms for big EO data management; Table S4: EO thematic products.

Author Contributions: Conceptualization, A.A., S.M., R.J.M., E.R.W. and J.L.; methodology, A.A., S.M., R.J.M., E.R.W. and J.L.; software, A.A.; validation, A.A., S.M., R.J.M., E.R.W. and J.L.; formal analysis, A.A. and E.R.W.; investigation, A.A.; resources, A.A., S.M., R.J.M., E.R.W. and J.L.; data curation, A.A.; writing—original draft preparation, A.A.; writing—review and editing, A.A., S.M., R.J.M., E.R.W. and J.L.; visualization, A.A. and E.R.W.; supervision, S.M., R.J.M., E.R.W. and J.L.; project administration, S.M.; funding acquisition, S.M., R.J.M., and E.R.W. All authors have read and agreed to the published version of the manuscript.

Funding: This research was funded by Natural Environment Research Council (NERC) SCENARIO Doctoral Training Partnership, Grant/Award NE/L002566/1, CASE award partner the National Physical Laboratory (NPL) and the APC was funded through the University of Surrey.

Institutional Review Board Statement: Not applicable.

Informed Consent Statement: Not applicable.

Data Availability Statement: Not applicable.

Acknowledgments: This research was supported by the SCENARIO Doctoral Training Partnership of the UK Natural Environment Research Council (NERC) with PhD funding for the first author. We thank the National Physical Laboratory (NPL) for co-funding and supervision support as the CASE award partner for this Ph.D. research.

Conflicts of Interest: The authors declare no conflict of interest. The co-funder had a role in the design of the study, in the collection, analyses and interpretation of data, in the writing of the manuscript, and in the decision to publish the results.

\section{References}

1. UN. Rio 20+ United Nations Conference on Sustainable Development-The Future We Want. Available online: https:// sustainabledevelopment.un.org/content/documents/733FutureWeWant.pdf (accessed on 19 August 2021).

2. UN. A/Res/70/1 Transforming Our World: The 2030 Agenda for Sustainable Development, 21 October 2015. Available online: https://www.un.org/en/development/desa/population/migration/generalassembly/docs/globalcompact/A_RES_ 70_1_E.pdf (accessed on 19 August 2021).

3. UN. Tier Classification for Global SDG Indicators (updated 29 March 2021). Available online: https://unstats.un.org/sdgs/files/ Tier\%20Classification\%20of\%20SDG\%20Indicators_29\%20Mar\%202021_web.pdf (accessed on 18 August 2021).

4. UN. SDG indicator Metadata. Available online: https://unstats.un.org/sdgs/metadata/files/Metadata-01-01-01a.pdf (accessed on 18 August 2021).

5. UN. SDG Tier Classification. Available online: https://unstats.un.org/sdgs/iaeg-sdgs/tier-classification/ (accessed on 18 August 2021).

6. SDSN. Data for Development: A needs Assessment for SDG Monitoring and Statistical Capacity Development. Available online: https://sustainabledevelopment.un.org/content/documents/2017Data-for-Development-Full-Report.pdf (accessed on 17 August 2021).

7. Rajabifard, A. Sustainable Development Goals Connectivity Dilemma; CRC Press: Boca Raton, FL, USA, 2019.

8. Avtar, R.; Aggarwal, R.; Kharrazi, A.; Kumar, P.; Kurniawan, T.A. Utilizing geospatial information to implement SDGs and monitor their Progress. Environ. Monit. Assess. 2020, 192, 35. [CrossRef] [PubMed]

9. UN-GGIM. The Global Statistical Geospatial Framework. Available online: https://ggim.un.org/meetings/GGIM-committee/ 9th-Session/documents/The_GSGF.pdf (accessed on 17 August 2021).

10. UN-GGIM. The Territorial Dimension in SDG Indicators: Geospatial Data Analysis and its Integration with Statistical Data. Available online: https:/ / un-ggim-europe.org/wp-content/uploads/2019/05/UN_GGIM_08_05_2019-The-territorial-dimensionin-SDG-indicators-Final.pdf (accessed on 19 August 2021). 
11. OECD. Overview: What will it take for data to enable development? In Development Co-operation Report 2017; Data for Development, OECD Publishing: Paris, France, 2017. [CrossRef]

12. Bill-Weilandt, A.; Bonino, C.; Diakite, T.; Freitas, L.; Hauray, G. Monitoring Progress Towards the SDGs: The Proliferation of Quantification in International Development Policy and Practice. Available online: https:/ / forccast.hypotheses.org/files/2017/0 6/PSIA-2016-Monitoring_Progress_Towards_the_SDGs.pdf (accessed on 18 August 2021).

13. Grant, M.J.; Booth, A. A typology of reviews: An analysis of 14 review types and associated methodologies. Health Info Libr. J. 2009, 26, 91-108. [CrossRef]

14. Andries, A.; Morse, S.; Murphy, R.; Lynch, J.; Woolliams, E.; Fonweban, J. Translation of Earth observation data into sustainable development indicators: An analytical framework. Sustain. Dev. 2018, 27, 366-376. [CrossRef]

15. Andries, A.; Morse, S.; Murphy, R.J.; Lynch, J.; Woolliams, E.R. Seeing Sustainability from Space: Using Earth Observation Data to Populate the UN Sustainable Development Goal Indicators. Sustainability 2019, 11, 5062. [CrossRef]

16. Cázarez-Grageda, K.; Zougbede, K. National SDG Review: Data Challenges and Opportunities. Available online: https: / / paris21.org/sites/default/files/inline-files/National-SDG_Review2019_rz.pdf (accessed on 17 August 2021).

17. Sarvajayakesavalu, S. Addressing challenges of developing countries in implementing five priorities for sustainable development goals. Ecosyst. Health Sustain. 2017, 1, 1-4. [CrossRef]

18. Lu, Y.; Nakicenovic, N.; Visbeck, M.; Stevance, A.-S. Policy: Five priorities for the UN Sustainable Development Goals. Nature 2015, 520, 432-433. [CrossRef]

19. Kindornay, S.; Bhattacharya, D.; Higgins, K. Implementing Agenda 2030: Unpacking the Data Revolution at Country Level. Available online: https:/ / www.think-asia.org/handle/11540/6956 (accessed on 18 August 2021).

20. SciDevNet. Africa's 'Sluggish Data Collection Needs a Revolution'. Available online: https://www.scidev.net/global/news/ africa-s-sluggish-data-collection-needs-a-revolution/ (accessed on 18 August 2021).

21. Bhattacharya, D.; Khan, T.; Rezbana, U.; Mostaque, L. Moving forward with the SDGs: Implementation Challenges in developing countries. Cent. Policy Dialogue (CPD). Bangladish Civ. Soc. Think Thank. 2016, 1-41. Available online: https://library.fes.de/pdffiles/iez/12673.pdf (accessed on 18 August 2021).

22. SDSN. State of Development Data Funding. Available online: https://opendatawatch.com/wp-content/uploads/2016/09/ development-data-funding-2016.pdf (accessed on 18 August 2021).

23. GEO. Responses to the Questionnaire on Uses of Earth Observation Data for SDG Analysis and Reporting by GEO Member Countries. Available online: https:/ / eo4sdg.org/wp-content/uploads/2020/03/Responses-to-Questionnaire-on-the-Uses-ofEarth-Observation-Data-for-SDG-analysis-and-reporting-by-GEO-Member-Countries.pdf (accessed on 18 August 2021).

24. United Nations Satellite Imagery and Geo-Spatial Data Task Team. Earth Observations for Official Statistics Satellite Imagery and Geospatial Data Task Team Report. 2017, p. 170. Available online: https://unstats.un.org/bigdata/task-teams/earthobservation/UNGWG_Satellite_Task_Team_Report_WhiteCover.pdf (accessed on 18 August 2021).

25. Denis, G.; Claverie, A.; Pasco, X.; Darnis, J.-P.; de Maupeou, B.; Lafaye, M.; Morel, E. Towards disruptions in Earth observation? New Earth Observation systems and markets evolution: Possible scenarios and impacts. Acta Astronaut. 2017, 137, 415-433. [CrossRef]

26. Wood, D.; Stober, K.J. Small Satellites Contribute to the United Nations' Sustainable Development Goals. In Proceedings of the Conference on Small Satellites, Logan, UT, USA, 4-9 August 2018; pp. 1-9.

27. Kavvada, A.; Metternicht, G.; Kerblat, F.; Mudau, N.; Haldorson, M.; Laldaparsad, S.; Friedl, L.; Held, A.; Chuvieco, E. Towards delivering on the Sustainable Development Goals using Earth observations. Remote Sens. Environ. 2020, 247, 111930. [CrossRef]

28. Gorelick, N.; Hancher, M.; Dixon, M.; Ilyushchenko, S.; Thau, D.; Moore, R. Google Earth Engine: Planetary-scale geospatial analysis for everyone. Remote Sens. Environ. 2017, 202, 18-27. [CrossRef]

29. PARIS21. A Road Map for a Country-Led Data Revolution; OECD Publishing: Paris, France, 2015. [CrossRef]

30. NASA. Earth Science Applied Sciences. Available online: https://appliedsciences.nasa.gov (accessed on 17 August 2021).

31. ESA and the Sustainable Development Goals. Available online: https://www.esa.int/Enabling_Support/Preparing_for_the_ Future/Space_for_Earth/ESA_and_the_Sustainable_Development_Goals (accessed on 10 October 2021).

32. Jerven, M. Benefits and Costs of the Data for Development Targets for the Post-2015 Development Agenda; Copenhagen Consensus Center: Tewksbury, MA, USA, 2014; p. 14.

33. Jerven, M. How Much Will a Data Revolution in Development Cost? Forum Dev. Stud. 2017, 44, 31-50. [CrossRef]

34. Demombynes, G.; Sandefur, J. Costing a data revolution. Cent. Glob. Dev. Work. Pap. 2014, 14, 1-12. [CrossRef]

35. Cochran, F.; Daniel, J.; Jackson, L.; Neale, A. Earth Observation-Based Ecosystem Services Indicators for National and Subnational Reporting of the Sustainable Development Goals. Remote Sens Env. 2020, 244, 1-111796. [CrossRef]

36. ESA. Satellite Earth Observation in Support of the Sustainable Development Goals. Available online: http://eohandbook.com/ sdg/files/CEOS_EOHB_2018_SDG.pdf (accessed on 17 August 2021).

37. Khorram, S.; Frank, H.K.; van der Wiele, C.F.; Stacy, A.C.N. Introduction: Remote Sensing; SpringerBriefs in Space Development: Berlin/Heidelberg, Germany, 2012.

38. Freeden, W.; Nashed, M.; Sonar, T. Handbook on Geomathematics; Springer: Berlin/Heidelberg, Germany, 2010 ; Volume 2, p. 1371.

39. World Meteorological Organization-Observing Systems Capability Analysis and Review Tool (OSCAR). Available online: https:/ / www.wmo-sat.info/oscar/satellites (accessed on 17 August 2021). 
40. Directory EO Portal Missions Database. Available online: https://directory.eoportal.org/web/eoportal/satellite-missions/a (accessed on 18 August 2021).

41. CEOS Database. Available online: http://Database.Eohandbook.Com/about.Aspx (accessed on 17 August 2021).

42. Kumar, P.S.J.; Huan, T.L. Earth Science and Remote Sensing Applications; Springer: Berlin/Heidelberg, Germany, 2018 ; Volume 43.

43. Liang, S.; Wang, J. Chapter 1-A systematic view of remote sensing. In Advanced Remote Sensing, 2nd ed.; Academic Press: Cambridge, MA, USA, 2020; pp. 1-57.

44. Harris, R.; Baumann, I. Open data policies and satellite Earth observation. Space Policy 2015, 32, 44-53. [CrossRef]

45. Woodcock, C.E.; Allen, R.; Anderson, M.; Belward, A.; Bindschadler, R.; Cohen, W.; Gao, F.; Goward, S.N.; Helder, D.; Helmer, E.; et al. Free Access to Landsat Imagery. Science 2008, 320, 1011. [CrossRef]

46. Turner, W.; Rondinini, C.; Pettorelli, N.; Mora, B.; Leidner, A.K.; Szantoi, Z.; Buchanan, G.; Dech, S.; Dwyer, J.; Herold, M.; et al. Free and open-access satellite data are key to biodiversity conservation. Biol. Conserv. 2015, 182, 173-176. [CrossRef]

47. Rudd, J.D.; Roberson, G.T.; Classen, J.J. Application of satellite, unmanned aircraft system, and ground-based sensor data for precision agriculture: A review. In Proceedings of the 2017 ASABE Annual International Meeting, Spokane, WA, USA, 16-19 July 2017; p. 1.

48. Andries, A.; Morse, S.; Murphy, R.J.; Lynch, J.; Mota, B.; Woolliams, E.R. Can Current Earth Observation Technologies Provide Useful Information on Soil Organic Carbon Stocks for Environmental Land Management Policy? Sustainability 2021, 13, 12074. [CrossRef]

49. Allen, M. Contextual Overview of the use of Remote Sensing data Within CAP Eligibility Inspection and Control. Available online: http:/ / www.niassembly.gov.uk/globalassets/documents/raise/publications/2015/dard/3115.pdf (accessed on 17 August 2021).

50. Sadlier, G.; Flytkjær, R.; Sabri, S.; Robin, N. Value of Satellite-Derived Earth Observation Capabilities to the UK Government Today and by 2020; London Economics: London, UK, 2018.

51. Watmough, G.R.; Marcinko, C.L.J.; Sullivan, C.; Tschirhart, K.; Mutuo, P.K.; Palm, C.A.; Svenning, J.C. Socioecologically informed use of remote sensing data to predict rural household poverty. Proc. Natl. Acad. Sci. USA 2019, 116, 1213-1218. [CrossRef] [PubMed]

52. Bruzelius, E.; Le, M.; Kenny, A.; Downey, J.; Danieletto, M.; Baum, A.; Doupe, P.; Silva, B.; Landrigan, P.J.; Singh, P. Satellite images and machine learning can identify remote communities to facilitate access to health services. J. Am. Med. Inform. Assoc. JAMIA 2019, 26, 806-812. [CrossRef]

53. Gomes, V.; Queiroz, G.; Ferreira, K. An Overview of Platforms for Big Earth Observation Data Management and Analysis. Remote Sens. 2020, 12, 1253. [CrossRef]

54. GEF. Earth Observation and the Global Environment Facility (GEF)-Technical Guide. Available online: https://stapgef.org/sites/ default/files/2021-04/Earth\%20Observation\%20and\%20the\%20GEF\%20Technical\%20Guide_web.pdf (accessed on 17 August 2021).

55. USGS. Available online: http:/ / earthexplorer.usgs.gov/ (accessed on 18 August 2021).

56. GloVis. Available online: https://glovis.usgs.gov/ (accessed on 18 August 2021).

57. NASA. Earth Data. Available online: https:/ / earthdata.nasa.gov/earth-observation-data (accessed on 18 August 2021).

58. ESA. Available online: https://landsat8portal.eo.esa.int/portal/ (accessed on 18 August 2021).

59. ASTER. Available online: https://ssl.jspacesystems.or.jp/ersdac/GDEM/E/index.html (accessed on 18 August 2021).

60. USGS. Earth Resources Observation and Science (EROS) Centre. Available online: https://www.usgs.gov/centers/eros/science/ usgs-eros-archive-products-overview?qt-science_center_objects=0\#qt-science_center_objects (accessed on 18 August 2021).

61. Copernicus. Open Access Hub. Available online: https://sentinel.esa.int/web/sentinel/ (accessed on 18 January 2022).

62. SentinelHub. Sentinel Playground. Available online: https://apps.sentinel-hub.com/sentinel-playground (accessed on 18 August 2021).

63. Hub, S. EO Browser. Available online: https://apps.sentinel-hub.com/eo-browser/ (accessed on 18 August 2021).

64. NASA. Worldview. Available online: https:/ / worldview.earthdata.nasa.gov/ (accessed on 18 August 2021).

65. NCDC. National Centers for Environmental Information. Available online: https://www.ncdc.noaa.gov/data-access/quick-links (accessed on 18 August 2021).

66. MapBox. Remote Pixel. Available online: https://search.remotepixel.ca/\#3/40/-70.5 (accessed on 18 August 2021).

67. CSA. Earth Observation Data Management System. Available online: https://www.asc-csa.gc.ca/eng/satellites/radarsat/ (accessed on 18 August 2021).

68. INPE. Catálogo de Imagens. Available online: http://www.dgi.inpe.br/CDSR/ (accessed on 18 August 2021).

69. ISRO. Bhuvan. Available online: https://bhuvan.nrsc.gov.in/bhuvan_links.php (accessed on 18 August 2021).

70. NASA. Global Precipitation Measurements. Available online: https://gpm.nasa.gov/data/directory (accessed on 18 August 2021).

71. EUMETSAT. Available online: http://www.eumetsat.int/website/home/Data/DataDelivery/ (accessed on 18 August 2021).

72. NOAA. CLASS. Available online: https://www.avl.class.noaa.gov/saa/products/welcome (accessed on 18 August 2021).

73. Amazon. Earth on AWS. Available online: https://aws.amazon.com/earth/?nc1=h_ls (accessed on 18 August 2021).

74. Google Earth Engine. Available online: https:/ / explorer.earthengine.google.com/\#workspace (accessed on 29 July 2021).

75. ZoomEarth. Available online: https:// zoom.earth/ (accessed on 18 August 2021).

76. MAXAR. Open Data. Available online: https://www.maxar.com/open-data/ (accessed on 18 August 2021). 
77. JAXA. ALOS 3D WORLD. Available online: https://www.eorc.jaxa.jp/ALOS/aw3d30/1_map_v2003.htm (accessed on 18 August 2021).

78. ESRI. Esri ArcGIS Online Image Services. Available online: http://www.arcgis.com/home/gallery.html (accessed on 18 August 2021).

79. NERC. CEDA Archive (Part of NERC Environmental Data Service). Available online: http://archive.ceda.ac.uk/ (accessed on 18 August 2021).

80. NASA. Alaska Satellite Facility. Available online: https://asf.alaska.edu/ (accessed on 18 August 2021).

81. Probst, L.; Frideres, L.; Cambier, B.; Duval, J.P.; Roth, M.; Lu-Dac, C. Space Tech and Services Applications Related to Earth Observation; European Union Business Innovation Observatory: Luxembourg, 2016; Available online: https://ec.europa.eu/docsroom/ documents/16591/attachments/1/translations/en/renditions/native (accessed on 10 January 2022).

82. ESA. Thematic Exploitation Platforms Overview. Available online: https://eo4society.esa.int/thematic-exploitation-platformsoverview/ (accessed on 17 August 2021).

83. FAO. WaPOR Database Methodology: Level 1 Data. Remote Sensing for Water Productivity Technical Report: Methodology Series. Available online: http:/ / www.fao.org/fileadmin/user_upload/faoweb/RS-WP/pdf_files/Web_WaPOR-beta_Methodology_ document_Level1.pdf (accessed on 18 August 2021).

84. Gonzalez-Roglich, M.; Zvoleff, A.; Noon, M.; Liniger, H.; Fleiner, R.; Harari, N.; Garcia, C. Synergizing global tools to monitor progress towards land degradation neutrality: Trends.Earth and the World Overview of Conservation Approaches and Technologies sustainable land management database. Environ. Sci. Policy 2019, 93, 34-42. [CrossRef]

85. Hansen, M.C.; Potapov, P.V.; Moore, R.; Hancher, M.; Turubanova, S.A.; Tyukavina, A.; Thau, D.; Stehman, S.V.; Goetz, S.J.; Loveland, T.R.; et al. High-resolution global maps of 21st-century forest cover change. Science 2013, 342, 850-853. [CrossRef]

86. Li, W.; MacBean, N.; Ciais, P.; Defourny, P.; Lamarche, C.; Bontemps, S.; Houghton, R.A.; Peng, S. Gross and net land cover changes in the main plant functional types derived from the annual ESA CCI land cover maps (1992-2015). Earth Syst. Sci. Data 2018, 10, 219-234. [CrossRef]

87. Marselis, S.M.; Abernethy, K.; Alonso, A.; Armston, J.; Baker, T.R.; Bastin, J.F.; Bogaert, J.; Boyd, D.S.; Boeckx, P.; Burslem, D.F.R.P.; et al. Evaluating the potential of full-waveform lidar for mapping pan-tropical tree species richness. Glob. Ecol. Biogeogr. 2020, 29, 1799-1816. [CrossRef]

88. Showstack, R. Global Forest Watch Initiative Provides Opportunity for Worldwide Monitoring. Eos Trans. Am. Geophys. Union 2014, 95, 77-79. [CrossRef]

89. UNESCAP. Innovative Big Data Approaches for Capturing and Analyzing Data to Monitor and Achieve the SDGs; United Nations: Bangkok, Thailand, 2017; p. 137. Available online: https:/ /hdl.handle.net/20.500.12870/2862 (accessed on 15 October 2021).

90. Ferreira, B.; Iten, M.; Silva, R.G. Monitoring sustainable development by means of earth observation data and machine learning: A review. Environ. Sci. Eur. 2020, 32, 1-17. [CrossRef]

91. Lewis, A.; Oliver, S.; Lymburner, L.; Evans, B.; Wyborn, L.; Mueller, N.; Raevksi, G.; Hooke, J.; Woodcock, R.; Sixsmith, J.; et al. The Australian Geoscience Data Cube-Foundations and lessons learned. Remote Sens. Environ. 2017, 202, 276-292. [CrossRef]

92. CEOS. Available online: https:/ / ceos.org/ard/ (accessed on 15 October 2021).

93. Butler, D. Earth observation enters next phase. Nature 2014, 508, 160-161. [CrossRef]

94. Guo, H.-D.; Zhang, L.; Zhu, L.-W. Earth observation big data for climate change research. Adv. Clim. Change Res. 2015, 6, 108-117. [CrossRef]

95. Garcia-Pineda, O.; Staples, G.; Jones, C.E.; Hu, C.; Holt, B.; Kourafalou, V.; Graettinger, G.; DiPinto, L.; Ramirez, E.; Streett, D.; et al. Classification of oil spill by thicknesses using multiple remote sensors. Remote Sens. Environ. 2020, 236, 1-15. [CrossRef]

96. Badarinath, K.V.S.; Sharma, A.R.; Kharol, S.K. Forest fire monitoring and burnt area mapping using satellite data: A study over the forest region of Kerala State, India. Int. J. Remote Sens. 2011, 32, 85-102. [CrossRef]

97. Muckenhuber, S. High resolution sea ice monitoring using space borne Synthetic Aperture Radar. Ph.D. Thesis, the University of Bergen, Bergen, Norway, 2017.

98. Simonneaux, V.; Duchemin, B.; Helson, D.; Er-Raki, S.; Olioso, A.; Chehbouni, A.G. The use of high-resolution image time series for crop classification and evapotranspiration estimate over an irrigated area in central Morocco. Int. J. Remote Sens. 2010, 29, 95-116. [CrossRef]

99. Jeong, S.J.; Ho, C.H.; Choi, S.D.; Kim, J.; Lee, E.J.; Gim, H.J. Satellite data-based phenological evaluation of the nationwide reforestation of South Korea. PLoS ONE 2013, 8, e58900. [CrossRef] [PubMed]

100. Kaplan, G.; Avdan, U. Mapping and Monitoring Wetlands Using Sentinel-2 Satellite Imagery. ISPRS Ann. Photogramm. Remote Sens. Spat. Inf. Sci. 2017, IV, 271-277. [CrossRef]

101. Sallustio, L.; De Toni, A.; Strollo, A.; Di Febbraro, M.; Gissi, E.; Casella, L.; Geneletti, D.; Munafo, M.; Vizzarri, M.; Marchetti, M. Assessing habitat quality in relation to the spatial distribution of protected areas in Italy. J. Env. Manag. 2017, 201, 129-137. [CrossRef] [PubMed]

102. Andries, A.; Murphy, R.J.; Morse, S.; Lynch, J. Earth Observation for Monitoring, Reporting, and Verification within Environmental Land Management Policy. Sustainability 2021, 13, 9105. [CrossRef]

103. Sawaya, K.E.; Olmanson, L.G.; Heinert, N.J.; Brezonik, P.L.; Bauer, M.E. Extending satellite remote sensing to local scales: Land and water resource monitoring using high-resolution imagery. Remote Sens. Environ. 2003, 88, 144-156. [CrossRef] 
104. Liu, L.; Tang, H.; Caccetta, P.; Lehmann, E.A.; Hu, Y.; Wu, X. Mapping afforestation and deforestation from 1974 to 2012 using Landsat time-series stacks in Yulin District, a key region of the Three-North Shelter region, China. Environ. Monit. Assess 2013, 185, 9949-9965. [CrossRef] [PubMed]

105. Hislop, S.; Haywood, A.; Jones, S.; Soto-Berelov, M.; Skidmore, A.; Nguyen, T.H. A satellite data driven approach to monitoring and reporting fire disturbance and recovery across boreal and temperate forests. Int. J. Appl. Earth Obs. Geoinf. 2020, 87, 102034. [CrossRef]

106. Sheffield, J.; Wood, E.F.; Pan, M.; Beck, H.; Coccia, G.; Serrat-Capdevila, A.; Verbist, K. Satellite Remote Sensing for Water Resources Management: Potential for Supporting Sustainable Development in Data-Poor Regions. Water Resour. Res. 2018, 54, 9724-9758. [CrossRef]

107. Hede, A.N.H.; Koike, K.; Kashiwaya, K.; Sakurai, S.; Yamada, R.; Singer, D.A. How can satellite imagery be used for mineral exploration in thick vegetation areas? Geochem. Geophys. Geosystems 2017, 18, 584-596. [CrossRef]

108. Zhang, X.; Friedl, M.A.; Schaaf, C.B.; Strahler, A.H.; Hodges, J.C.F.; Gao, F.; Reed, B.C.; Huete, A. Monitoring vegetation phenology using MODIS. Remote Sens. Environ. 2003, 84, 471-475. [CrossRef]

109. Liu, Y.; Zhou, Y.; Lu, N.; Tang, R.; Liu, N.; Li, Y.; Yang, J.; Jing, W.; Zhou, C. Comprehensive assessment of Fengyun-3 satellites derived soil moisture with in-situ measurements across the globe. J. Hydrol. 2021, 594, 125949. [CrossRef]

110. Zhou, T.; Geng, Y.; Chen, J.; Pan, J.; Haase, D.; Lausch, A. High-resolution digital mapping of soil organic carbon and soil total nitrogen using DEM derivatives, Sentinel-1 and Sentinel-2 data based on machine learning algorithms. Sci. Total Env. 2020, 729, 138244. [CrossRef] [PubMed]

111. Bolch, T. Climate change and glacier retreat in northern Tien Shan (Kazakhstan/Kyrgyzstan) using remote sensing data. Glob. Planet. Change 2007, 56, 1-12. [CrossRef]

112. Fretwell, P.T.; Trathan, P.N.; Scales, K.; Bouchet, P. Discovery of new colonies by Sentinel2 reveals good and bad news for emperor penguins. Remote Sens. Ecol. Conserv. 2020, 7, 139-153. [CrossRef]

113. Merchant, C.J.; Embury, O.; Bulgin, C.E.; Block, T.; Corlett, G.K.; Fiedler, E.; Good, S.A.; Mittaz, J.; Rayner, N.A.; Berry, D.; et al Satellite-based time-series of sea-surface temperature since 1981 for climate applications. Sci Data 2019, 6, 223. [CrossRef]

114. Groom, S.; Sathyendranath, S.; Ban, Y.; Bernard, S.; Brewin, R.; Brotas, V.; Brockmann, C.; Chauhan, P.; Choi, J.-k.; Chuprin, A.; et al. Satellite Ocean Colour: Current Status and Future Perspective. Front. Mar. Sci. 2019, 6. [CrossRef]

115. Nerem, R.S.; Beckley, B.D.; Fasullo, J.T.; Hamlington, B.D.; Masters, D.; Mitchum, G.T. Climate-change-driven accelerated sea-level rise detected in the altimeter era. Proc. Natl. Acad. Sci. USA 2018, 115, 2022-2025. [CrossRef]

116. Xing, Q.; An, D.; Zheng, X.; Wei, Z.; Wang, X.; Li, L.; Tian, L.; Chen, J. Monitoring seaweed aquaculture in the Yellow Sea with multiple sensors for managing the disaster of macroalgal blooms. Remote Sens. Environ. 2019, 231, 111279. [CrossRef]

117. Biermann, L.; Clewley, D.; Martinez-Vicente, V.; Topouzelis, K. Finding Plastic Patches in Coastal Waters using Optical Satellite Data. Sci Rep 2020, 10, 5364. [CrossRef] [PubMed]

118. Melet, A.; Teatini, P.; Le Cozannet, G.; Jamet, C.; Conversi, A.; Benveniste, J.; Almar, R. Earth Observations for Monitoring Marine Coastal Hazards and Their Drivers. Surv. Geophys. 2020, 41, 1489-1534. [CrossRef]

119. Fretwell, P.T.; Staniland, I.J.; Forcada, J. Whales from space: Counting southern right whales by satellite. PLoS ONE 2014, 9 , e88655. [CrossRef] [PubMed]

120. Transforming Satellite Data into Weather Forecasts. Available online: https://eos.org/science-updates/transforming-satellitedata-into-weather-forecasts (accessed on 17 August 2021).

121. Liou, Y.-A.; Kar, S. Evapotranspiration Estimation with Remote Sensing and Various Surface Energy Balance Algorithms-A Review. Energies 2014, 7, 2821-2849. [CrossRef]

122. Brown, A.; Hayward, T.; Timmis, R.; Wade, R.; Pope, R.; Trent, T.; Boesch, H.; Guillo, R. Satellite Measurements of Air Quality and Greenhouse Gases: Application to Regulatory Activities Report; Environment Agency: Bristol, UK, 2021; p. 156.

123. Chahine, M.; Pagano, T.; Aumann, H.; Atlas, R.; Barnet, C.; Blaisdell, J.; Chen, L.; Divakarla, M.; Fetzer, E.; Goldberg, M.; et al AIRS: Improving Weather Forecasting and Providing New Data on Greenhouse Gases. Bull. Am. Meteorol. Soc. BULL. AMER. METEOROL. SOC. 2006, 87, 911-926. [CrossRef]

124. Ialongo, I.; Virta, H.; Eskes, H.; Hovila, J.; Douros, J. Comparison of TROPOMI/Sentinel-5 Precursor $\mathrm{NO}_{2}$ observations with ground-based measurements in Helsinki. Atmos. Meas. Tech. 2020, 13, 205-218. [CrossRef]

125. Boersma, K.F.; Eskes, H.J.; Veefkind, J.P.; Brinksma, E.J.; Sneep, M.; van den Oord, G.H.J.; Levelt, P.F.; Stammes, P.; Gleason, J.F.; Bucsela, E.J.; et al. Near-real time retrieval of tropospheric $\mathrm{NO}_{2}$ from OMI. Atmos. Chem. Phys. 2007, 7, 2103-2118. [CrossRef]

126. Gauthier, J.-F.; Germain, S. From Data to Actionable Insight: Monitoring Fugitive Methane Emissions at Oil and Gas Facilities Using Satellites. In Proceedings of the Abu Dhabi International Petroleum Exhibition \& Conference, Abu Dhabi, United Arab Emirates, 11-14 November 2019.

127. Bucsela, E.J.; Celarier, E.A.; Wenig, M.O.; Gleason, J.F.; Veefkind, J.P.; Boersma, K.F.; Brinksma, E.J. Algorithm for NO/sub 2/ vertical column retrieval from the ozone monitoring instrument. IEEE Trans. Geosci. Remote Sens. 2006, 44, 1245-1258. [CrossRef]

128. Carboni, E.; Mather, T.A.; Schmidt, A.; Grainger, R.G.; Pfeffer, M.A.; Ialongo, I.; Theys, N. Satellite-derived sulfur dioxide (SO 2) emissions from the 2014-2015 Holuhraun eruption (Iceland). Atmos. Chem. Phys. 2019, 19, 4851-4862. [CrossRef]

129. Le Cozannet, G.; Kervyn, M.; Russo, S.; Ifejika Speranza, C.; Ferrier, P.; Foumelis, M.; Lopez, T.; Modaressi, H. Space-Based Earth Observations for Disaster Risk Management. Surv. Geophys. 2020, 41, 1209-1235. [CrossRef] 
130. Joyce, K.E.; Samsonov, S.V.; Levick, S.R.; Engelbrecht, J.; Belliss, S. Mapping and monitoring geological hazards using optical, LiDAR, and synthetic aperture RADAR image data. Nat. Hazards 2014, 73, 137-163. [CrossRef]

131. Mateo-Garcia, G.; Veitch-Michaelis, J.; Smith, L.; Oprea, S.V.; Schumann, G.; Gal, Y.; Baydin, A.G.; Backes, D. Towards global flood mapping onboard low cost satellites with machine learning. Sci Rep 2021, 11, 7249. [CrossRef] [PubMed]

132. Chen, B.; Peng, K.; Parkinson, C.; Bertozzi, A.L.; Slough, T.L.; Urpelainen, J. Modeling illegal logging in Brazil. Res. Math. Sci. 2021, 8, 1-21. [CrossRef]

133. Hodler, R.; Raschky, P.A. Regional Favoritism. Q. J. Econ. 2014, 129, 995-1033. [CrossRef]

134. Elvidge, C.; Zhizhin, M.; Baugh, K.; Hsu, F.-C. Automatic Boat Identification System for VIIRS Low Light Imaging Data. Remote Sens. 2015, 7, 3020-3036. [CrossRef]

135. Martinez, L. How Much Should We Trust the Dictator's GDP Growth Estimates? Univ. Chic. Harris Sch. Public Policy 2019. [CrossRef]

136. Straka, W.; Seaman, C.; Baugh, K.; Cole, K.; Stevens, E.; Miller, S. Utilization of the Suomi National Polar-Orbiting Partnership (NPP) Visible Infrared Imaging Radiometer Suite (VIIRS) Day/Night Band for Arctic Ship Tracking and Fisheries Management. Remote Sens. 2015, 7, 971-989. [CrossRef]

137. Hoppe, E.; Bruckno, B.; Campbell, E.; Acton, S.; Vaccari, A.; Stuecheli, M.; Bohane, A.; Falorni, G.; Morgan, J. Transportation Infrastructure Monitoring Using Satellite Remote Sensing. In Materials and Infrastructures 1; Torrenti, J.-M., Torre, F.L., Eds.; John Wiley \& Sons: Paris, France, 2016; pp. 185-198.

138. ESA. The Impact of Space Data on Smart Transport and Logistics. Available online: https://business.esa.int/news/impact-spacedata-smart-transport-logistics (accessed on 17 August 2021).

139. Sutton, P.; Roberts, D.; Elvidge, C.; Baugh, K. Census from Heaven: An estimate of the global human population using night-time satellite imagery. Int.,J. Remote Sens. 2010, 22, 3061-3076. [CrossRef]

140. Ghosh, T.; Anderson, S.; Elvidge, C.; Sutton, P. Using Nighttime Satellite Imagery as a Proxy Measure of Human Well-Being Sustainability 2013, 5, 4988-5019. [CrossRef]

141. Zhao, F.; Song, L.; Peng, Z.; Yang, J.; Luan, G.; Chu, C.; Ding, J.; Feng, S.; Jing, Y.; Xie, Z. Night-Time Light Remote Sensing Mapping: Construction and Analysis of Ethnic Minority Development Index. Remote Sens. 2021, 13, 2129. [CrossRef]

142. Engstrom, R.N.; Hersh, J.; Newhouse, D. Poverty from Space: Using High-Resolution Satellite Imagery for Estimating Economic Well-Being; Policy Research Working Paper No. 8284; World Bank: Washington, DC, USA, 2017; Available online: https: / / openknowledge.worldbank.org/handle/10986/29075 (accessed on 18 January 2022).

143. Henderson, J.V.; Storeygard, A.; Weil, D.N. A Bright Idea for Measuring Economic Growth. Am. Econ. Rev. 2011, 101, 194-199. [CrossRef]

144. Al-Bilbisi, H. Spatial Monitoring of Urban Expansion Using Satellite Remote Sensing Images: A Case Study of Amman City, Jordan. Sustainability 2019, 11, 2260. [CrossRef]

145. Singhal, A.; Sahu, S.; Chattopadhyay, S.; Mukherjee, A.; Bhanja, S.N. Using night time lights to find regional inequality in India and its relationship with economic development. PLoS ONE 2020, 15, e0241907. [CrossRef]

146. Warth, G.; Braun, A.; Assmann, O.; Fleckenstein, K.; Hochschild, V. Prediction of Socio-Economic Indicators for Urban Planning Using VHR Satellite Imagery and Spatial Analysis. Remote Sens. 2020, 12, 1730. [CrossRef]

147. Shi, K.; Yu, B.; Huang, Y.; Hu, Y.; Yin, B.; Chen, Z.; Chen, L.; Wu, J. Evaluating the Ability of NPP-VIIRS Nighttime Light Data to Estimate the Gross Domestic Product and the Electric Power Consumption of China at Multiple Scales: A Comparison with DMSP-OLS Data. Remote Sens. 2014, 6, 1705-1724. [CrossRef]

148. Doll, C.N.H.; Pachauri, S. Estimating rural populations without access to electricity in developing countries through night-time light satellite imagery. Energy Policy 2010, 38, 5661-5670. [CrossRef]

149. Froehlich, A.; Tăiatu, C.M. Practical Use of Satellite Data in Support of Human Rights. In Space in Support of Human Rights; Springer: Berlin/Heidelberg, Germany, 2020; pp. 49-124.

150. Quinn, J.A.; Nyhan, M.M.; Navarro, C.; Coluccia, D.; Bromley, L.; Luengo-Oroz, M. Humanitarian applications of machine learning with remote-sensing data: Review and case study in refugee settlement mapping. Philos. Trans. R. Soc. A Math. Phys. Eng. Sci. 2018, 376, 20170363. [CrossRef]

151. McDonald, G.G.; Costello, C.; Bone, J.; Cabral, R.B.; Farabee, V.; Hochberg, T.; Kroodsma, D.; Mangin, T.; Meng, K.C.; Zahn, O. Satellites can reveal global extent of forced labor in the world's fishing fleet. Proc. Natl. Acad. Sci. USA 2021, 118 , e2016238117. [CrossRef]

152. Lai, K.Y.; Sarkar, C.; Ni, M.Y.; Cheung, L.W.T.; Gallacher, J.; Webster, C. Exposure to light at night (LAN) and risk of breast cancer: A systematic review and meta-analysis. Sci. Total Environ. 2021, 762, 143159. [CrossRef] [PubMed]

153. Malone, J.B.; Bergquist, R.; Martins, M.; Luvall, J.C. Use of Geospatial Surveillance and Response Systems for Vector-Borne Diseases in the Elimination Phase. Trop. Med. Infect. Dis. 2019, 4, 15. [CrossRef]

154. Anderson, K.; Ryan, B.; Sonntag, W.; Kavvada, A.; Friedl, L. Earth observation in service of the 2030 Agenda for Sustainable Development. Geo-Spat. Inf. Sci. 2017, 20,77-96. [CrossRef]

155. GEO. EO4SDG Earth Observations in Service of the 2030 Agenda for Sustainable Development; Group on Earth Observations: Geneva, Switzerland, 2019; p. 32. Available online: https:/ / earthobservations.org/documents/gwp20_22/eo_for_sustainable_ development_goals_ip.pdf (accessed on 10 January 2022). 
156. O'Connor, B.; Moul, K.; Pollini, B.; DeLamo, X.; Simonson, W. EO4SDG: Compendium of Earth Observation Contributions to the SDG Targets and Indicators. 2020, p. 165. Available online: https://eo4society.esa.int/2021/01/15/compendium-of-eocontributions-to-the-sdgs-just-released/ (accessed on 18 January 2022).

157. Estoque, R. A Review of the Sustainability Concept and the State of SDG Monitoring Using Remote Sensing. Remote Sens. 2020, 12, 1770. [CrossRef]

158. DigitalGlobe. Satellite Data's Role in Supporting Sustainable Development Goals Empowering Organizations with Earth Observation Geospatial Information \& Big Data; DigitalGlobe: Denver, CO, USA, 2020; p. 22.

159. Curzi, G.; Modenini, D.; Tortora, P. Large Constellations of Small Satellites: A Survey of Near Future Challenges and Missions. Aerospace 2020, 7, 133. [CrossRef]

160. PlanetLab. Available online: https:/ / www.planet.com (accessed on 17 August 2021).

161. Engstrom, R.; Newhouse, D.; Soundararajan, V. Estimating small-area population density in Sri Lanka using surveys and Geo-spatial data. PLoS ONE 2020, 15, e0237063. [CrossRef]

162. DigitalGlobe. Available online: https://blog.maxar.com/earth-intelligence/2017/eliminating-malaria-with-the-power-of-thecrowd (accessed on 17 August 2021).

163. Gender and Urban Mobility in Chile. Available online: https://thegovlab.org/project/project-gender-and-urban-mobility-inchile (accessed on 18 August 2021).

164. The Living Lib. Available online: https://thelivinglib.org/selected-readings-on-data-gender-and-mobility (accessed on 20 August 2021).

165. Gauvin, L.; Tizzoni, M.; Piaggesi, S.; Young, A.; Adler, N.; Verhulst, S.; Ferres, L.; Cattuto, C. Gender gaps in urban mobility. Humanit. Soc. Sci. Commun. 2020, 7, 11. [CrossRef]

166. Purdy, R.; Harris, R.; Carver, J.; Slater, D. Action B8: Remote sensing-Phase 1 (Research) Final Report. 2017. Available online: https:/ / www.sepa.org.uk/media/311269/1sw-b8-phase-1-final-report-v10.pdf (accessed on 18 January 2022).

167. The Conversation. Available online: https://theconversation.com/the-eye-in-the-sky-that-can-spot-illegal-rubbish-dumpsfrom-space-98395 (accessed on 17 August 2021).

168. Paoli, A.D.; Addeo, F. Assessing SDGs: A methodology to measure sustainability. Athens, J. Soc. Sci. 2019, 6, 229-250. [CrossRef]

169. Tremblay, D.; Fortier, F.; Boucher, J.F.; Riffon, O.; Villeneuve, C. Sustainable development goal interactions: An analysis based on the five pillars of the 2030 agenda. Sustain. Dev. 2020, 28, 1584-1596. [CrossRef]

170. IRP; UNEP. Resource Efficiency for Sustainable Development: Key Messages for the Group of 20; United Nations Environment Programme: Nairobi, Kenya, 2018; p. 49. Available online: https://www.resourcepanel.org/reports/resource-efficiencysustainable-development (accessed on 18 January 2022).

171. Geniaux, G. Sustainable Development Indicator Frameworks and Initiatives; SEAMLESS: Avignon, France, 2009 ; p. 150.

172. Azevedo, G.; Costa, H.; Farias Filho, J. Measuring Well-Being Through OECD Better Life Index: Mapping the Gaps. In Proceedings of the International Joint Conference on Industrial Engineering and Operations Management, Rio de Janeiro, Brazil, 8-11 July 2020.

173. Schwartz, S.H. An Overview of the Schwartz Theory of Basic Values. Online Read. Psychol. Cult. 2012, 2. [CrossRef]

174. Rutstein, S.O.; Rojas, G. Guide to DHS statistics- Demographic and Health Surveys; ICF: Rockville, MD, USA, $2006 ;$ p. 171.

175. Hicks, C.C.; Levine, A.; Agrawal, A.; Basurto, X.; Breslow, S.J.; Carothers, C.; Charnley, S.; Coulthard, S.; Dolsak, N.; Donatuto, J. Engage key social concepts for sustainability. Science 2016, 352, 38-40. [CrossRef]

176. King, C. Partnership Effectiveness Continuum: A Research-Based Tool for Use in Developing, Assessing, and Improving Partnerships; Education Development Center: Waltham, MA, USA, 2014; p. 21.

177. Pham, T.-T.-H.; Apparicio, P.; Gomez, C.; Weber, C.; Mathon, D. Towards a rapid automatic detection of building damage using remote sensing for disaster management. Disaster Prev. Manag. 2014, 23, 53-66. [CrossRef]

178. Patino, J.E.; Duque, J.C.; Pardo-Pascual, J.E.; Ruiz, L.A. Using remote sensing to assess the relationship between crime and the urban layout. Appl. Geogr. 2014, 55, 48-60. [CrossRef]

179. Ghosh, T.; Anderson, S.; Powell, R.L.; Sutton, P.C.; Elvidge, C.D. Estimation of Mexico's Informal Economy and Remittances Using Nighttime Imagery. Remote Sens. 2009, 1, 418-444. [CrossRef]

180. Yazdani, M.; Nguyen, M.H.; Block, J.; Crawl, D.; Zurutuza, N.; Kim, D.; Hanson, G.; Altintas, I. Scalable Detection of Rural Schools in Africa Using Convolutional Neural Networks and Satellite Imagery. In Proceedings of the 2018 IEEE/ACM International Conference on Utility and Cloud Computing Companion (UCC Companion), Zurich, Switzerland, 17-20 December 2018; pp. 142-147.

181. UNICEF. Available online: https:/ / projectconnect.unicef.org/ (accessed on 18 August 2021).

182. Min, B.; Gaba, K.M.; Sarr, O.F.; Agalassou, A. Detection of rural electrification in Africa using DMSP-OLS night lights imagery. Int. J. Remote Sens. 2013, 34, 8118-8141. [CrossRef]

183. Dugoua, E.; Kennedy, R.; Urpelainen, J. Satellite data for the social sciences: Measuring rural electrification with night-time lights. Int. J. Remote Sens. 2018, 39, 2690-2701. [CrossRef]

184. Pekel, J.F.; Cottam, A.; Gorelick, N.; Belward, A.S. High-resolution mapping of global surface water and its long-term changes. Nature 2016, 540, 418-422. [CrossRef] 
185. Andries, A.; Morse, S.; Murphy, R.; Woolliams, E.; Jim, L. Assessing Education from Space: Using satellite Earth Observation to assess pupil density in primary schools in rural areas of Nigeria. In Proceedings of the Sustainability in Transforming Societies of the 26th Annual Conference of the International Sustainable Development Research Society, Budapest, Hungary, 15-17 July 2020; p. 1008

186. Andries, A.; Morse, S.; Murphy, R.J.; Lynch, J.; Woolliams, E.R. Assessing education from space: Using satellite Earth Observation to quantify overcrowding in primary schools in rural areas of Nigeria. Sustainability 2021, in press.

187. Bhatt, S.; Weiss, D.; Cameron, E.; Bisanzio, D.; Mappin, B.; Dalrymple, U.; Battle, K.; Moyes, C.; Henry, A.; Eckhoff, P. The effect of malaria control on Plasmodium falciparum in Africa between 2000 and 2015. Nature 2015, 526, 207-211. [CrossRef] [PubMed]

188. Evans, J.; van Donkelaar, A.; Martin, R.V.; Burnett, R.; Rainham, D.G.; Birkett, N.J.; Krewski, D. Estimates of global mortality attributable to particulate air pollution using satellite imagery. Env. Res 2013, 120, 33-42. [CrossRef]

189. Mohamed, M.F. Satellite data and real time stations to improve water quality of Lake Manzalah. Water Sci. 2015, 29, 68-76. [CrossRef]

190. SDG Indicator Metadata 13.2.2. Available online: https:// unstats.un.org/sdgs/metadata/files/Metadata-13-02-02.pdf (accessed on 20 October 2021).

191. Copernicus Climate Change Service. Available online: https://www.iup.uni-bremen.de/carbon_ghg/docs/C3S/CDR3_2003-20 18/PQAR/C3S_D312b_Lot2.2.3.2-v1.0_PQAR-GHG_MAIN_v3.1.pdf (accessed on 17 August 2021).

192. Climate Data Store. Available online: https://cds.climate.copernicus.eu/\#!/home (accessed on 15 September 2021).

193. Sentinel-5P Air Quality Data Look Promising. Available online: https://www.ecmwf.int/en/newsletter/157/news/sentinel-5pair-quality-data-look-promising (accessed on 15 October 2021).

194. Magro, C.; Nunes, L.; Gonçalves, O.C.; Neng, N.R.; Nogueira, J.M.; Rego, F.C.; Vieira, P. Atmospheric Trends of $\mathrm{CO}^{2}$ and $\mathrm{CH}_{4}$ from Extreme Wildfires in Portugal Using Sentinel-5P TROPOMI Level-2 Data. Fire 2021, 4, 25. [CrossRef]

195. UNEP; CCAC. Global Methane Assessment: Benefits and Costs of Mitigating Methane Emissions; United Nations Environment Programme: Nairobi, Kenya, 2021; p. 173.

196. Wu, D.; Lin, J.C.; Oda, T.; Kort, E.A. Space-based quantification of per capita $\mathrm{CO}_{2}$ emissions from cities. Environ. Res. Lett. 2020, 15, 035004. [CrossRef]

197. Pandey, S.; Gautam, R.; Houweling, S.; van der Gon, H.D.; Sadavarte, P.; Borsdorff, T.; Hasekamp, O.; Landgraf, J.; Tol, P.; van Kempen, T.; et al. Satellite observations reveal extreme methane leakage from a natural gas well blowout. Proc. Natl. Acad. Sci. USA 2019, 116, 26376-26381. [CrossRef]

198. Bamber, J.; Bates, P.; Brindley, H.; Evans, B.; Jackson, T.; Merchant, C.; Davey, M.P.; Palmer, P.; Scott, M.; Spencer, T. Space-based Earth Observations for Climate Security. COP 26 Universityies Network Briefing. 2021. Available online: https:/ / www.gla.ac. uk/media/Media_792662_smxx.pdf (accessed on 18 January 2022).

199. Seeds, D. India Lights. Available online: http://india.nightlights.io/\#/nation/2006/12 (accessed on 17 August 2021).

200. Medium-Voltage Distribution (Predictive). Available online: https://energydata.info/dataset/medium-voltage-distributionpredictive (accessed on 15 September 2021).

201. Model Documentation. Available online: https://github.com/facebookresearch/many-to-many-dijkstra (accessed on 17 August 2021).

202. UNESC. Exploring Space Technologies for Sustainable Development and the Benefits of International Research Collaboration in this Context. Available online: https://unctad.org/system/files/official-document/ecn162020d3_en.pdf (accessed on 17 August 2021).

203. FAO. Challenges and Opportunities for Reporting on SDG Indicators-Information Seminar for Permanent Representatives. 2020. Available online: https:/ / www.fao.org/3/ca9190en/ca9190en.pdf (accessed on 18 January 2022).

204. Sudmanns, M.; Tiede, D.; Lang, S.; Bergstedt, H.; Trost, G.; Augustin, H.; Baraldi, A.; Blaschke, T. Big Earth data: Disruptive changes in Earth observation data management and analysis? Int J Digit Earth 2019, 13, 832-850. [CrossRef]

205. MacFeely, S. The Big (data) Bang: Opportunities and Challenges for CompilingSDGIndicators. Glob. Policy 2019, 10, 121-133. [CrossRef]

206. Perez, A.; Yeh, C.; Azzari, G.; Burke, M.; Lobell, D.; Ermon, S. Poverty prediction with public landsat 7 satellite imagery and machine learning. arXiv 2017, arXiv:1711.03654.

207. Malarvizhi, K.; Kumar, S.V.; Porchelvan, P. Use of high resolution Google Earth satellite imagery in landuse map preparation for urban related applications. Procedia Technol. 2016, 24, 1835-1842. [CrossRef]

208. Bernknopf, R.; Kuwayama, Y.; Gibson, R.; Blakely, J.; Mabee, B.; Clifford, T.J.; Quayle, B.; Epting, J.; Hardy, T.; Goodrich, D. The Cost-Effectiveness of Satellite Earth Observations to Inform a Post-Wildfire Response; Valuables an RFF/NASA CONSORTIUM; RFF: Washington, DC, USA, 2019; Available online: https:/ / media.rff.org/documents/Valuables_Wildfires.pdf (accessed on 10 January 2022).

209. Vuolo, F.; Essl, L.; Atzberger, C. Costs and benefits of satellite-based tools for irrigation management. Front. Environ. Sci. 2015, 3 , 1-12. [CrossRef]

210. Cerbaro, M.; Morse, S.; Murphy, R.; Lynch, J.; Griffiths, G. Challenges in Using Earth Observation (EO) Data to Support Environmental Management in Brazil. Sustainability 2020, 12, 10411. [CrossRef]

211. UN. Integrating Statistical Geospatial and Other Big Data to Leave no one Behind 5 March 2018. Available online: https: //media.un.org/en/asset/k1w/k1wkg1785y (accessed on 24 August 2021). 
212. UN. Virtual High-Level Forum Events on United Nations Global Geospatial. Available online: https://ggim.un.org/meetings / 2020/Virtual_HLF (accessed on 25 August 2021).

213. Tscherning, K.; Helming, K.; Krippner, B.; Sieber, S.; y Paloma, S.G. Does research applying the DPSIR framework support decision making? Land Use Policy 2012, 29, 102-110. [CrossRef]

214. Pissourios, I.A. An interdisciplinary study on indicators: A comparative review of quality-of-life, macroeconomic, environmental, welfare and sustainability indicators. Ecol. Indic. 2013, 34, 420-427. [CrossRef]

215. Hák, T.; Moldan, B.; Dahl, A.L. Sustainability Indicators: A Scientific Assessment; Island Press: Washington, DC, USA, 2007.

216. Andries, A.M.S.; Lynch, J.M.; Woolliams, E.R.; Fonweban, J.; Murphy, R.J. Translation of Earth Observation data into sustainable development indicators: An analytical framework. In Proceedings of the 24th International Sustainable Development Research Society Conference-Actions for a Sustainable World: From Theory to Practice, Messina, Italy, 13-15 June 2018 ; p. 17.

217. Masó, J.; Serral, I.; Domingo-Marimon, C.; Zabala, A. Earth observations for sustainable development goals monitoring based on essential variables and driver-pressure-state-impact-response indicators. Int. J. Digit. Earth 2019, 13, 217-235. [CrossRef]

218. Cozzolino, E.; Lasta, C.A. Use of VIIRS DNB satellite images to detect jigger ships involved in the Illex argentinus fishery. Remote Sens. Appl. : Soc. Environ. 2016, 4, 167-178. [CrossRef]

219. Park, J.; Lee, J.; Seto, K.; Hochberg, T.; Wong, B.A.; Miller, N.A.; Takasaki, K.; Kubota, H.; Oozeki, Y.; Doshi, S.; et al. Illuminating dark fishing fleets in North Korea. Sci. Adv. 2020, 6, eabb1197. [CrossRef] [PubMed]

220. Bell, S.; Morse, S. Participatory approaches for the development and evaluation of sustainability indicators. In Routledge HandBook of Sustainability Indicators; Routledge: Oxford, UK, 2018; pp. 188-203. 